\title{
Synopsis of Orchidaceae from Serra do Urubu: an area of montane forest, Pernambuco State, Brazil
}

\author{
Edlley Pessoa ${ }^{1,3}$ and Marccus Alves ${ }^{2}$
}

Received: 22.07.2014; accepted: 22.09.2014

\begin{abstract}
Synopsis of Orchidaceae from Serra do Urubu: an area of montane forest, Pernambuco State, Brazil). This study provides a survey of Orchidaceae species in an area of montane Atlantic Forest in the State of Pernambuco, Brazil. The study area comprises two conservation units (RPPN Frei Caneca and RPPN Pedra D'Anta), forming together the Serra do Urubu, which is located in the border of the Borborema plateau. Orchidaceae is represented in this study area by 81 species and 50 genera. Epidendrum L. (10 spp.) and Habenaria Willd. (four spp.) are the most representative genera. The subtribes Laeliinae (22 spp.) and Pleurothallidinae (14 spp.) together represent about half of the number of species. The high number of orchid species distinguishes Serra do Urubu as one of the richest areas for the family in the Atlantic Forest in northeastern Brazil. Our study also provides 18 new records of species to Pernambuco as well as reporting on about $40 \%$ of the species and $60 \%$ of the genera cited to the State. Campylocentrum pernambucense, Cattleya labiata, Cattleya granulosa, Phragmipedium sargentianum and Zygostates bradei are cited as endangered, 14 species are endemic to the Atlantic Forest, and other seven have distributions restricted to northeastern Brazil. All these facts reinforce the importance of this area as well as management strategies for the conservation of Orchidaceae.
\end{abstract}

Keywords: hotspot, monocots, northeastern Brazil, orchids

RESUMO - (Sinopse de Orchidaceae na Serra do Urubu: uma área de floresta montana do Estado de Pernambuco, Brasil). Esse estudo apresenta um inventário taxonômico das espécies da família Orchidaceae em uma área de Floresta Atlântica no Estado de Pernambuco, Brasil. A área de estudo compreende duas unidades de conservação (RPPN Frei Caneca e RPPN Pedra D'Anta) que formam juntas a Serra do Urubu, localizada no limite oriental do planalto da Borborema. Orchidaceae está representada na área por 81 espécies e 50 gêneros, sendo Epidendrum L. (10 spp.) e Habenaria Willd. (quatro spp.) os mais ricos. As subtribos Laeliinae (22 spp.) e Pleurothallidinae (14 spp.) juntas correspondem a cerca da metade do número de espécies. O alto número de orquídeas evidencia a Serra do Urubu como a área mais rica em espécies da família para Floresta Atlântica do Nordeste do Brasil. Esse estudo apresenta 18 novos registros para o Estado de Pernambuco, e inclui cerca de $40 \%$ das espécies e $60 \%$ dos gêneros citados para o Estado. Campylocentrum pernambucense, Cattleya labiata, Cattleya granulosa, Phragmipedium sargentianum e Zygostates bradei são citados como ameaçados de extinção, 14 espécies são endêmicas da Floresta Atlântica, e sete tem distribuição restrita a região Nordeste do Brasil, isso reforça a importância da área para conservação da família Orchidaceae.

Palavras-chave: hotspot, monocotiledôneas, Nordeste do Brasil, orquídeas

\section{Introduction}

The Atlantic Forest biome is the second largest forested formation in South America, but due to the high level of deforestation, and the high number of endemic species, it is considered one of the world's hotspots in biodiversity (Mittermeyer et al. 2004).
More than 20,000 species of Angiosperms have been recorded for the Atlantic Forest, and ca. 8,000 (40\%) are considered endemic to this formation (Myers et al. 2000).

Historical factors point out the northern portion of such ecosystem as the most endangered mainly because it is composed of small and isolated fragments

1. Programa de Pós-Graduação em Biologia Vegetal, Universidade Federal de Pernambuco, Departamento de Botânica, Recife, PE, Brazil

2. Universidade Federal de Pernambuco, Departamento de Botânica, 50670-901 Recife, PE, Brazil

3. Corresponding author: edlley_max@hotmail.com 
in a matrix of sugarcane (Ranta et al. 1998). The Atlantic Forest north of Rio São Francisco [also known as Pernambuco Endemism Center (Prance 1982)] has been far less studied than the southern portion. Furthermore, due to the several new taxa which have been recently described (Alves-Araújo \& Alves 2011, 2012a, 2012b, Amorim \& Alves 2012, Melo \& Alves 2012, Araújo \& Alves 2013, Amorin et al. 2013, Costa-Lima \& Alves 2013, Lourenço et al. 2013, Terra et al. 2013, Costa-Lima et al. 2014, Pessoa \& Alves 2014, Pessoa et al. 2014a, 2014b), the Pernambuco Endemism Center is pontentially much more diverse than it is currently known.

In the State of Pernambuco only $4.6 \%$ of the original Atlantic Forest remains (Secretaria de Ciência, Tecnologia e Meio Ambiente 1994), and the only two surveys of the family in these forest fragments were carried out by Siqueira-Filho \& Felix (2006) and Pessoa \& Alves (2012). According to Stehmann et al. (2009), Orchidaceae is very well represented in the Atlantic Forest, with ca. 1400 species (Barros et al. 2014). They also stressed that from the 180 species cited for the State of Pernambuco, $90 \%$ of them occur in the forest fragments of this ecosystem.

The aim of this study was to provide a survey of the Orchidaceae species in a montane area of Atlantic Forest in Pernambuco State, northeastern Brazil. Our survey includes an identification key, pictures or illustrations, and comments on geographical distribution, ecology as well as main characters of the species.

\section{Material and methods}

The study area comprises two conservation units: Reserva Particular do Patrimônio Natural (RPPN) Frei Caneca and Reserva Particular do Patrimônio Natural (RPPN) Pedra D'Anta. Both areas are located in the Serra do Urubu $\left(8^{\circ} 42^{\prime} \mathrm{S}\right.$ and $\left.35^{\circ} 50^{\prime} \mathrm{W}\right)$, within the municipalities of Lagoa dos Gatos, São Benedito do Sul and Jaqueira, in the eastern border of the Borborema plateau (Pernambuco State, northeastern Brazil).

The climate is considered tropical wet and dry (Aw sensu Köppen), with an annual average precipitation of $1200 \mathrm{~mm}$, and mean temperatures between $18-30^{\circ} \mathrm{C}$ (LAMEPE/ITEP). The site comprises Montane Dense Ombrophilous Forest based on the types of vegetation proposed by Veloso (1992).

The Serra do Urubu is mainly covered by forest with some exposed rocky outcrops and has an altitude of 600-750 m ASL. The lower elevation areas (300-400 m) are occupied by sugarcane crops.

The fieldwork was carried out from December 2010 to May 2013, covering eleven months of each year with the exception of February. The samples were submitted to the usual taxonomic procedures (Mori et al. 1985) and then deposited at the UFP herbarium, with duplicates sent to NY and RB, among other herbaria.

Samples previously collected from the study area were located and studied at the herbaria visited (ALCB, CEPEC, EAC, EAN, HST, HUEFS, IPA, JPB, MAC, PEUFR, RB and UFP; acronyms according to Thiers 2014).

Taxonomic identification was based upon the most important references [Dunsterville \& Garay (1959, 1961, 1965, 1966, 1972, 1976), Pabst \& Dungs (1975, 1977), Carnevali et al. (2003) and Toscanode-Brito \& Crib (2005)] and analysis of herbarium collections.

The morphological terminology follows Harris \& Harris (2001) and Gonçalves \& Lorenzi (2007). The data on geographical distribution of the species follows Barros et al. (2014) and Govaerts et al. (2014). Basionyms, whenever necessary, are provided after the accepted name as well as new synonyms.

\section{Results and Discussion}

Orchidaceae is represented in Serra do Urubu by 81 species and 50 genera. Epidendrum L. (10 spp.) and Habenaria Willd. (four spp.) are the most speciesrich genera. The subtribes Laeliinae (22 spp.) and Pleurothallidinae (14 spp.) represent together almost half of the total number of species found in the area. The diversity of orchid species in Serra do Urubu ranks the area as one of the richest for the family in the Atlantic Forest in northeastern Brazil (Pessoa \& Alves 2011, Pessoa \& Alves 2012, Marinho \& Azevedo 2013, Coelho \& Amorim 2014).

This study provides 18 new records of species to the State of Pernambuco. The results also encompass about $40 \%$ of the species and $60 \%$ of the genera cited to the State by Barros et al. (2014). The forested portion of Serra do Urubu is more speciesrich (65 spp.) than the rock outcrops (17 spp.), and only five species share both habitats. According to Barros et al. (2014), among the species found in the area, 14 are considered endemic to the Atlantic Forest, and seven are known only in northeastern 
Brazil, including a recently described one, Specklinia integripetala E.Pessoa \& F.Barros (Pessoa et al. 2014a). Campylocentrum pernambucense Hoehne, Cattleya labiata Lindl., Cattleya granulosa Lindl., Phragmipedium sargentianum (Rolfe) Rolfe and Zygostates bradei (Schltr.) Garay are cited as endangered by the Ministério do Meio Ambiente (2008), Biodiversitas (2008) and Martinelli \& Moraes (2013). These facts reinforce the value of the area for Orchid conservation.

When the data are compared to a lowland Atlantic Forest area in Pernambuco State [Usina São José,
Pessoa \& Alves (2012)], it is clear that both sites do not share the same compostion of the orchid flora (only 11 shared species). Around $80 \%$ of the species from the montane forest are not found in the lowland forest, which shows a strong split pattern in the orchid flora locally.

Seventeen species cited by Siqueira-Filho \& Felix (2006) for the same area were not found during our field trips nor located at the indicated herbaria. Due to the lack of vouchers to corroborate the occurrence of these species in the area, they were ruled out from the present study.

Key to the species of Orchidaceae from Serra do Urubu

1. Hemi-epiphyte herbs; internodes voluble

2. Leaves coriaceous, oblong; internodes $>9.0 \mathrm{~cm}$ long 80. Vanilla cf. pompona

2. Leaves membranaceous, elliptic; internodes $<7.0 \mathrm{~cm}$ long 79. Vanilla aff. mexicana

1. Epiphyte, rupiculous or terrestrial herbs; internodes not voluble

3. Inflorescence lateral

4. Pseudobulb absent

5. Leaves fleshy, coriaceous to sub-coriaceous; inflorescence many-flowered

6. Leaves cylindrical, apex acute; inflorescence $<0.8 \mathrm{~cm}$ long 12. Campylocentrum pernambucense

6. Leaves plane, apex 2-lobed; inflorescence $>1.3 \mathrm{~cm}$ long

7. Leaves oblong, coriaceous; spur slightly curved; fruits not-ribbed

10. Campylocentrum crassirhizum

7. Leaves oblong-elliptic, sub-coriaceous; spur strongly curved; fruits 6-ribbed

11. Campylocentrum micranthum

5. Leaves membranaceous; inflorescence 1-flowered

8. Leaves elliptic; not articulated; peduncle geniculate

18. Dichaea pendula

8. Leaves linear-oblong, articulated; peduncle non- geniculate

17. Dichaea panamensis

4. Pseudobulb present

9. Pseudobulb homoblastic; leaves distributed along the stem

16. Cyrtopodium flavum

9. Pseudobulb heteroblastic; leaves apical and/or basal

10. Pseudobulb longitudinally multi-sulcate; leaves plicate

34. Gongora vitorinoana

10. Pseudobulb not sulcate; leaves conduplicate

11. Inflorescence 1-flowered

12. Pseudobulbs apically 2-leaved

67. Rhetinantha notylioglossa

12. Pseudobulbs apically 1 -leaved

13. Sheaths that envelop the pseudobulbs without leaf blades

14. Inflorescence longer than 2 times the length of the pseudobulb

47. Maxillaria leucaimata

14. Inflorescence shorter than 2 times the length of the pseudobulb

15. Leaves sub-sessile; mid-lobe of the lip non- papillose .... 50. Mormolyca rufescens

15. Leaves long petiolate; mid-lobe of the lip papillose ..... 46. Mapinguari desvauxianus

13. Sheaths that envelop the pseudobulbs with leaf blades

16. Lip pandurate

17. Leaves discolorous; sepals $<2.0 \mathrm{~cm}$ long, the apex acute

39. Heterotaxis discolor

17. Leaves concolorous; sepals $\geq 2.5 \mathrm{~cm}$ long, the apex acuminate 
18. Apical leaf sessile; sepals $<1.8 \mathrm{~cm}$ long, elliptic

8. Camaridium carinatum

18. Apical leaf pseudo-petiolate; sepals $>3.5 \mathrm{~cm}$ long, lanceolate

48. Maxillaria ochroleuca

11. Inflorescence 2- to many-flowered

19. Flowers with spur

20. Terrestrial herbs; spur apically 2-lobed

55. Oeceoclades maculata

20. Epiphyte herbs; spur apically acute or rounded

21. Leaves green; inflorescence racemose

78. Trichocentrum fuscum

21. Leaves dark purple; inflorescence paniculate

15. Comparettia barkeri

19. Flowers without spur

22. Lateral sepals completely free

23. Pseudobulbs $>1.5 \mathrm{~cm}$ long; inflorescence congest; apex of the sepals acute, margin entire

9. Camaridium micranthum

23. Pseudobulbs $<0.8 \mathrm{~cm}$ long; inflorescence lax. apex of the sepals rounded, margin serrate 81. Zygostates bradei

22. Lateral sepals completely to partially connate

24. Lip clawed; callus or lamellaes absent

53. Notylia inversa

24. Lip without claw; callus or lamellaes present

25 . Flowers whitish; lateral sepals completely connate

68. Rodriguezia bahiensis

25 . Flowers yellowish and brownish; lateral sepals connate only up to the middle 26. Mid-lobe of the lip < lateral lobes; lip margin ciliate 32. Gomesa barbata 26. Mid-lobe of the lip > lateral lobes; lip margin entire

33. Gomesa hookeri

3. Inflorescence terminal

27. Pseudobulb present

28. Pseudobulb homoblastic

29. Epiphytic or rupiculous herbs; leaves conduplicate 60. Polystachya estrellensis

29. Terrestrial herbs; leaves plicate

30. Inflorescence umbellate; apex of the lip acute

45. Malaxis excavata

30. Inflorescence racemose; apex of the lip 2-lobed 44. Liparis nervosa

28. Pseudobulb heteroblastic

31. Pseudobulbs superposed; column with a foot

32. Pseudobulb 1-leaved; inflorescence pedunculate 70. Scaphyglottis fusiformis

32. Pseudobulb 2-leaved; inflorescence sessile

33. Sepals elliptic; lip not clawed, slightly 3-lobed

71. Scaphyglottis modesta

33. Sepals linear-oblanceolate; lip sub-clawed, entire 72. Scaphyglottis sickii

31. Pseudobulbs not superposed; column without a foot

34. Flowers ressupinate

35. Pseudobulbs 1-leaved, fusiform; sepals pinkish 14. Cattleya labiata

35. Pseudobulbs 2-leaved, cylindrical; sepals greenish to yellowish with brown spots

13. Cattleya granulosa

34. Flowers not ressupinate

36. Plants creeping with a branched rhizome; lip 3-lobed

64. Prosthechea pygmaea

36. Plants cespitose or shortly creeping; lip entire

37. Lip convex, $\leq 0.7 \mathrm{~cm}$ long 65. Prosthechea vespa

37. Lip concave, $>0.9 \mathrm{~cm}$ long 63. Prosthechea alagoensis

27. Pseudobulb absent

38. Leaves disposed in basal rosettes

39. Epiphytic herbs; inflorescence pendulous

31. Eurystyles cotyledon

39. Terrestrial or rupiculous herbs; inflorescence erect 
40. Flowers ressupinate; sepals $>0.5 \mathrm{~cm}$ long

41. Flowers without a spur or mentum; lip calceolate; column with a conspicuous shield-like staminode 57. Phragmipedium sargentianum

41. Flowers with spur or mentum; lip not calceolate; column without staminode

42. Leaves present at flowering; flowers yellowish-white 49. Mesadenella cuspidata

42. Leaves absent at flowering; flowers pinkish to magenta 69. Sacoila lanceolata

40. Flowers not ressupinate; sepals $\leq 0.3 \mathrm{~cm}$ long

43. Small rosettes, leaves ovate to wide elliptic, $\leq 4.5 \mathrm{~cm}$ long; flowers whitish

61. Prescottia oligantha

43. Large rosettes, leaves lanceolate to elliptic, $>5.0 \mathrm{~cm}$ long; flowers greenish 62. Prescottia plantaginifolia

38. Leaves only apical or distributed along the stem

44. Leaf 1, apical

45. Stem enveloped by lepanthiform sheaths

43. Lepanthopsis floripectren

45. Stem naked or enveloped by sheaths that are not lepanthiform

46. Leaves cylindrical

47. Inflorescence lax; sepals $>3.7 \mathrm{~cm}$ long

7. Brassavola tuberculata

47. Inflorescence congested; sepals $<1.0 \mathrm{~cm}$ long .

54. Octomeria alexandrii

46. Leaves plane

48. Dorsal sepal partially connate to the lateral sepals

49. Sepals connate at base forming a tube

76. Stelis deregularis

49. Sepals connate at base but not forming a tube

50. Leaves narrowly elliptic; lip with acuminate apex

75. Stelis aprica

50. Leaves wide elliptical to oblanceolate; lip with rounded apex

77. Stelis loefgrenii

48. Dorsal sepal free

51. Inflorescence peduncle $<1.0 \mathrm{~cm}$ long

52. Plants $<4.0 \mathrm{~cm}$ tall; inflorescence 1 -flowered

56. Pabstiella lingua

52. Plants $>10.0 \mathrm{~cm}$ tall; inflorescence multi-flowered

53. Lateral sepals completely connate

59. Pleurothallis ruscifolia

53. Lateral sepals connate only at base

51. Myoxanthus exasperatus

51. Inflorescence peduncle $\geq 1.0 \mathrm{~cm}$ long

54. Lateral sepals connate only at base to the middle

55. Plants $>8.0 \mathrm{~cm}$ tall; sepals $>1.0 \mathrm{~cm}$ long

4. Anathallis sclerophyla

55. Plants $<5.0 \mathrm{~cm}$ tall; sepals $<0.4 \mathrm{~cm}$ long

74. Specklinia integripetala

54. Lateral sepals completely connate

56. Flowers arising successively from the same point at the apex of the inflorescence

3. Anathallis barbulata

56. Flowers distributed along the inflorescence

57. Sepals $\leq 0.3 \mathrm{~cm}$ long; petals linear

58. Pleurothallis pruinosa

57. Sepals $>0.3 \mathrm{~cm}$ long; petals obovate to elliptic

58. Peduncle of the inflorescence longer than the subtended leaf .. 1. Acianthera glumacea

58. Peduncle of the inflorescence shorter than the subtended leaf....

2. Acianthera hygrophyla

44. Leaves 2 or more, distributed along the stem

59. Flowers with a developed spur

60. Petals entire

61. Apex of the petals truncate-sinuous; lip straight

35. Habenaria petalodes

61. Apex of the petals acute; lip with a lateral-constriction

62 . Leaves $\leq 5.0 \mathrm{~cm}$ long; pedicellate ovary $\leq 0.5 \mathrm{~cm}$ long .... 5. Aspidogyne argentea

62 . Leaves $>6.0 \mathrm{~cm}$ long; pedicellate ovary $>1.0 \mathrm{~cm}$ long

6. Aspidogyne foliosa 
60. Petals 2-lobed

63. Lateral sepals ovate; anterior lobe of the petals longer than the posterior lobe.... 36. Habenaria cryptophila

63. Lateral sepals lanceolate; anterior lobe of the petals as long as, or shorter than the posterior lobe

64. Posterior lobe of the petals elliptical; mid-lobe of the lip rhomboid; spur $\leq 3.0 \mathrm{~cm}$ long 37. Habenaria pratensis

64. Posterior lobe of the petals oblong to linear; mid-lobe of the lip linearoblong; spur $>3.0 \mathrm{~cm}$ long 38. Habenaria trifida

59. Flowers without a developed spur, sometimes with an inconspicuous mentum 65. Leaves cylindrical

66. Inflorescence sessile; flowers purple 41. Jacquiniella globosa

66. Inflorescence long-pedunculate; flowers yellowish to orange 42. Jacquiniella teretifolia

65. Leaves plane or plicate

67. Leaves plicate; sepals $>6.0 \mathrm{~cm}$ long 73. Sobralia liliastrum

67. Leaves conduplicate; sepals $<3.5 \mathrm{~cm}$ long

68. Column free or adnate only at base with the lip

69. Leaves ovate

66. Psilochilus modestus

69. Leaves linear, linear-oblong to linear elliptic

70. Floral bracts almost entirely covering the flower; flowers whitish 20. Elleanthus linifolius

70. Floral bracts covering only the base of the pedicellate ovary; flowers pinkish

71. Sepals free; base of the lip adnate to the column

19. Dimerandra emarginata

71. Sepals connate at base; lip free 40. Isochilus linearis

68. Column completely adnate to the lip

72. Peduncle two times longer than the rachis; flowers reddish

73. Terrestrial or rupiculous herbs; lateral lobes of the lip completely fringed 24. Epidendrum cinnabarinum

73. Epiphytic herbs; lateral lobes of the lip apically serrate

25. Epidendrum macrocarpum

72.Peduncle as long as, or shorter than the rachis; flowers greenish, whitish or yellowish

74. Floral bract completely or partially covering the pedicellate ovary 75. Stem not branched; lip sub-orbicular 28. Epidendrum rigidum

75. Stem branched; lip deltoid to ovate

76. Leaves linear-oblong; petals linear ...... 27. Epidendrum ramosum

76. Leaves lanceolate to elliptic; petals oblanceolate 28. Epidendrum strobilliferum

74. Floral bract short and not covering the pedicellate ovary 77. Stem branched 26. Epidendrum proligerum 77. Stem not branched

78. Inflorescence curved, paniculate 30. Epidendrum tridactylum

78. Inflorescence erect, simple (racemose or sub-corymbose)

79. Mid-lobe of the lip linear 23. Epidendrum carpophorum

79. Mid-lobe of the lip 2-lobed or orbicular 80 . Sepals $>3.0 \mathrm{~cm}$ long; mid-lobe of lip entire 
1. Acianthera glumacea (Lindl.) Pridgeon \& M.W.Chase, Lindleyana 16:243.2001 $\equiv$ Pleurothallis glumacea Lindl., Bot. Mag. 2: 355. 1837.

Figure 1a

This epiphyte differs from Acianthera hygrophyla by the peduncle of the inflorescence longer than the subtending leaf. It occurs in forested areas and it is endemic to the Atlantic Forest of Brazil (States of Pernambuco, Alagoas, Bahia, Minas Gerais, Espírito Santo, Rio de Janeiro, São Paulo, Paraná, Santa Catarina and Rio Grande do Sul) (Barros et al. 2014, Govaerts et al. 2014).

Examined material: BRAZIL. Pernambuco: Jaqueira, RPPN Frei Caneca, 11-III-2011, fl., E. Pessoa et al. 520 (NY, RB, UFP).

2. Acianthera hygrophila (Barb. Rodr.) Pridgeon \& M.W. Chase, Lindleyana 16: 244. $2001 \equiv$ Pleurothallis hygrophila Barb. Rodr., Gen. Sp. Orchid. 1: 7. 1877.

Figure $1 \mathrm{~b}$

This epiphyte differs from Acianthera glumacea by the peduncle of the inflorescence shorter than the subtending leaf. It occurs in forested areas and it is endemic to the Atlantic Forest of Argentina and Brazil (States of Minas Gerais, Espírito Santo, Rio de Janeiro, São Paulo, Paraná, Santa Catarina and Rio Grande do Sul) (Barros et al. 2014, Govaerts et al. 2014). It is a new record for the State of Pernambuco.

Examined material: BRAZIL. Pernambuco: Jaqueira, RPPN Frei Caneca, 30-V-2012, fl., E. Pessoa et al. 954 (NY, RB, UFP).

3. Anathallis barbulata (Lind1.) Pridgeon \& M.W.Chase, Lindleyana 16: 247. $2001 \equiv$ Pleurothallis barbulata Lindl., Fol. Orchid. 9: 40. 1859.

Figure 2a

This epiphyte is easily recognized among the Pleurothallidinae in the area by the long peduncle ( $>1.0 \mathrm{~cm}$ long), from where the purplish flowers arise successively from the same point. It occurs in forested areas, and it is widely distributed in the Neotropics, including Brazil (Barros et al. 2014, Govaerts et al. 2014).

Examined material: BRAZIL. Pernambuco: Jaqueira, RPPN Frei Caneca, 30-V-2012, fl., E. Pessoa 942 (UFP, RB); 29-I-2013, fl., E. Pessoa et al. 1052 (UFP); 11-III-2011, fl., E. Pessoa et al. 521 (UFP).
4. Anathallis sclerophylla (Lind1.) Pridgeon \& M.W.Chase, Lindleyana 16:250.2001 EPleurothallis sclerophylla Lindl., Edwards's Bot. Reg. 21: t. 1797. 1835.

Figure 1c

This epiphyte differs from Specklinia integripetala by the size of the plant $(>8.0 \mathrm{~cm}$ tall) and the longer sepals ( $>1.0 \mathrm{~cm}$ long). It occurs in forested areas and it is widely distributed in the Neotropics (Govaerts et al. 2014). In Brazil, it is found in the Amazon and Atlantic Forests (States of Roraima, Ceará, Pernambuco, Bahia, Minas Gerais, Espírito Santo, Rio de Janeiro, São Paulo, Paraná and Santa Catarina) (Barros et al. 2014).

Examined material: BRAZIL. Pernambuco: Jaqueira, RPPN Frei Caneca, 31-V-2012, fl., E. Pessoa et al. 959 (NY, RB, UFP).

5. Aspidogyne argentea (Vell.) Garay, Bradea 2: 203. $1977 \equiv$ Ophrys argentea Vell., Fl. Flumin. 9: t. 61. 1831.

Figure 1d

This terrestrial herb differs from Aspidogyne foliosa by its smaller leaves $(\leq 5.0 \mathrm{~cm}$ long) and shorter-pedicellate ovary $(\leq 0.5 \mathrm{~cm}$ long). It occurs in forested areas and it is known from Paraguay and Brazil (States of Distrito Federal, Ceará, Bahia, Minas Gerais, Espírito Santo, Rio de Janeiro, São Paulo, Paraná, Santa Catarina and Rio Grande do Sul) (Barros et al. 2014, Govaerts et al. 2014). It is a new record for the State of Pernambuco.

Examined material: BRAZIL. Pernambuco: Jaqueira, RPPN Frei Caneca, 18-XII-2004, fl., J.A. SiqueiraFilho 1451 (UFP); 27-XI-2001, fl., J.A. SiqueiraFilho 1200 (UFP); 13-XI-2003, fl., J.A.Siqueira-Filho 1419 (UFP); Lagoa dos Gatos, RPPN Pedra D’Anta, 17-XII-2010, fl., E. Pessoa et al. 427 (UFP).

6. Aspidogyne foliosa (Poepp. \& Endl.) Garay, Bradea 2: $201.1977 \equiv$ Pelexia foliosa Poepp. \& Endl., Nov. Gen. Sp. Pl. 2: 17. 1837.

Figure $2 b$

This terrestrial herb differs from Aspidogyne argentea by its longer leaves ( $>6.0 \mathrm{~cm}$ long) and longer-pedicellate ovary $(>1.0 \mathrm{~cm}$ long). It occurs in forested areas, and it is known from South America - French Guyana, Guyana, Suriname, Venezuela, Colombia, Ecuador, Peru, Bolivia, Paraguay and Brazil, where it is widely distributed (Barros et al. 2014, Govaerts et al. 2014). 

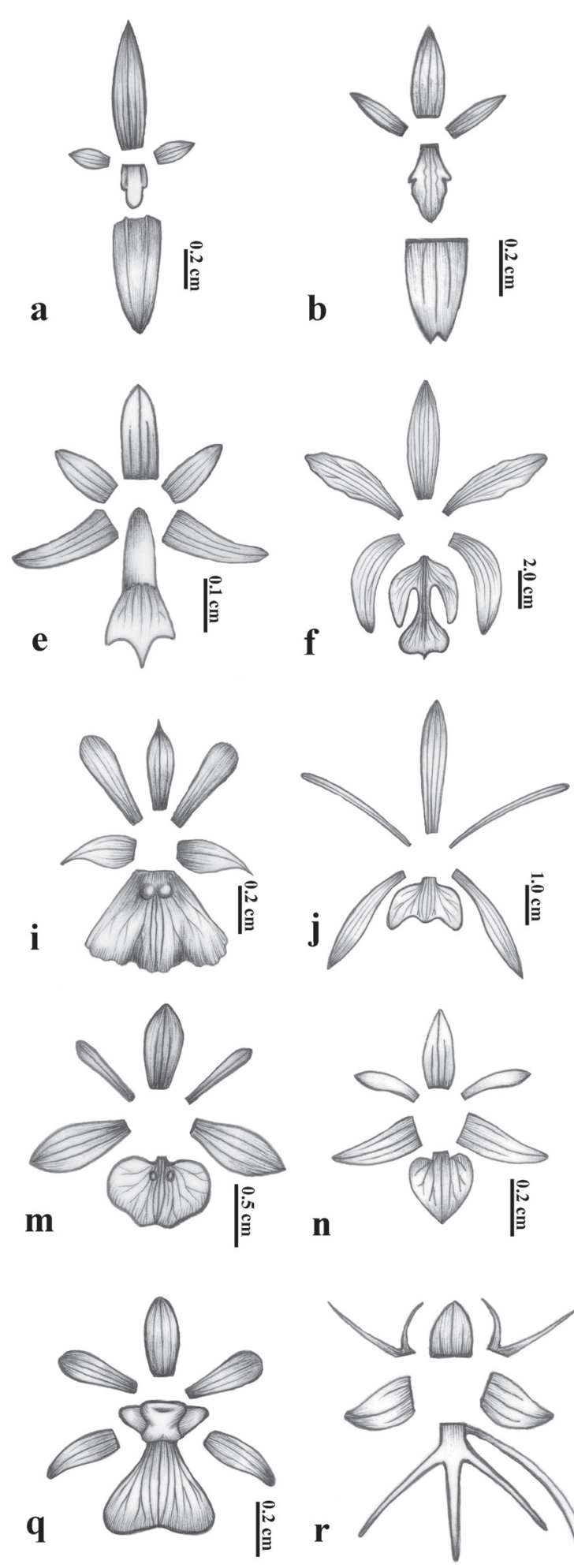
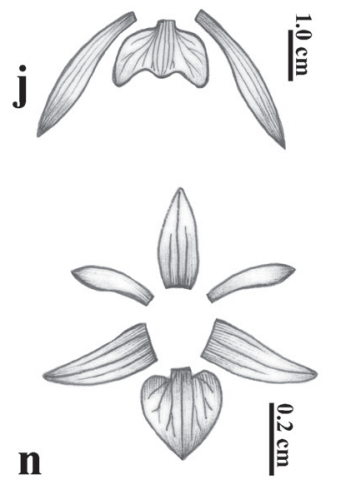

b

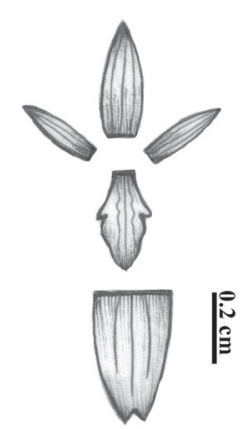

f

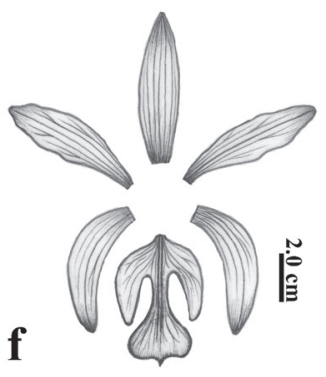

n
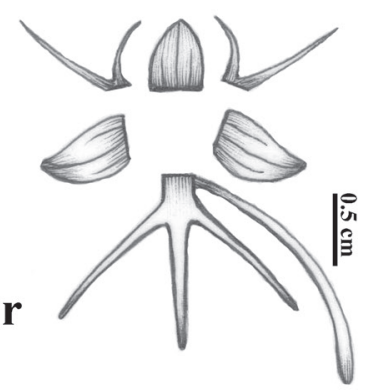
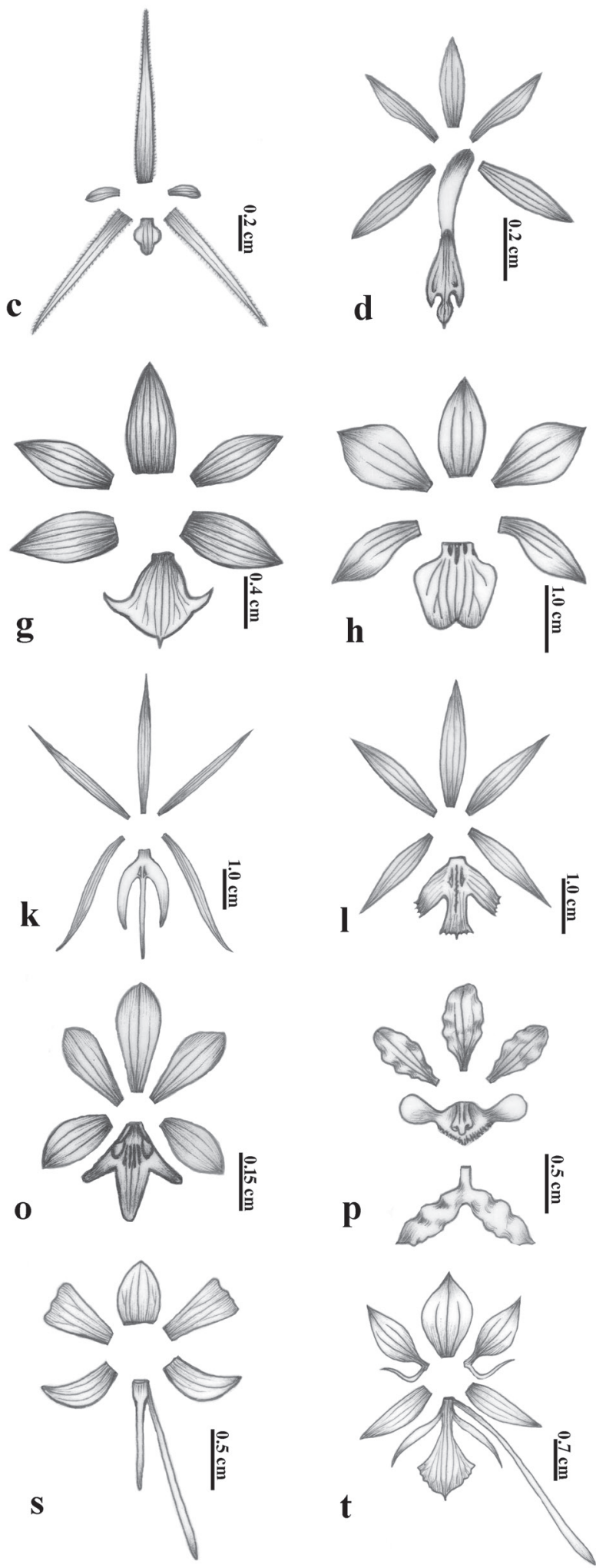

Figure 1. a. Acianthera glumacea. b. Acianthera hygrophyla. c. Anathallis sclerophylla. d. Aspidogyne argentea. e. Campylocentrum pernambucense. f. Cattleya granulosa. g. Dichaea pendula. h. Dimerandra emarginata. i. Elleanthus linifolius. j. Epidendrum anatipedium. k. Epidendrum carpophorum. 1. Epidendrum macrocarpum. m. Epidendrum proligerum. n. Epidendrum strobiliferum. o. Epidendrum tridactylym. p. Gomesa barbata. q. Gomesa hookeri. r. Habenaria cryptophila. s. Habenaria petalodes. t. Habenaria pratensis. 
Examined material: BRAZIL. Pernambuco: Jaqueira, RPPN Frei Caneca, 29-I-2013, fl., D. Araújo 2367 (RB, UFP); 11-III-2011, fl., E. Pessoa et al. 514 (UFP); Lagoa dos Gatos, RPPN Pedra D’Anta, 17-XII-2010, fl., E. Pessoa et al. 416 (NY, RB, UFP).

7. Brassavola tuberculata Hook., Bot. Mag. 56: t. 2878. 1829.

Figure 2c

This epiphyte or rupiculous herb can be confused vegetatively in the area with Octomeria alexandrii, but it is easily distinguished by the lax inflorescence and longer sepals ( $>3.7 \mathrm{~cm}$ long). It occurs on rock outcrops and it is endemic to Brazil (States of Rio Grande do Norte, Paraíba, Pernambuco, Alagoas, Sergipe, Bahia, Tocantins, Minas Gerais, Espírito Santo, Rio de Janeiro, São Paulo, Paraná, Santa Catarina and Rio Grande do Sul) (Barros et al. 2014, Govaerts et al. 2014).

Examined material: BRAZIL. Pernambuco: Jaqueira, RPPN Frei Caneca, 9-VII-1999, fl., J.A. SiqueiraFilho \& J.A. Vicente 985 (UFP).

8. Camaridium carinatum (Barb. Rodr.) Hoehne, Arq. Bot. Estado São Paulo 2: $72.1947 \equiv$ Maxillaria carinata Barb. Rodr., Gen. Sp. Orchid. 2: 206. 1882.

Figure 2d

This epiphyte differs from Maxillaria ochroleuca by its sessile apical leaf, yellow flowers and shorter sepals $(<1.8 \mathrm{~cm}$ long). It occurs in forested areas, and it is known from Guyana, Venezuela, Colombia, Ecuador, Peru and Brazil (States of Bahia, Minas Gerais, Espírito Santo, Rio de Janeiro, São Paulo, Paraná and Santa Catarina) (Barros et al. 2014, Govaerts et al. 2014). It is a new record for the State of Pernambuco.

Examined material: BRAZIL. Pernambuco: Brazil. Pernambuco: Jaqueira, RPPN Frei Caneca, 29-V-2012, fl. e fr., E. Pessoa et al. 931 (RB, UFP).

9. Camaridium micranthum M.A.Blanco, Lankesteriana

7: 520.2007 Scaphyglottis parviflora Poepp. \&

Endl., Nov. Gen. Sp. Pl. 1: 58. 1836.

Figure 2e

This epiphyte is easily recognized among the Maxillariinae in the area by the shorter $(<2.0 \mathrm{~cm}$ long) and congested many-flowered inflorescences.
It occurs in forested areas, and it is widely distributed in the Neotropics (Govaerts et al. 2014). In Brazil, it occurs in the Amazon and Atlantic Forests (States of Amazonas, Roraima, Amapá, Mato Grosso, Distrito Federal, Ceará, Minas Gerais, Rio de Janeiro, São Paulo, Paraná, Santa Catarina and Rio Grande do Sul) (Barros et al. 2014). It is a new record for the State of Pernambuco.

Examined material: BRAZIL. Pernambuco: Jaqueira, RPPN Frei Caneca, 29-V-2012, fl., E. Pessoa et al. 928 (RB, UFP).

10. Campylocentrum crassirhizum Hoehne, Arq. Bot. Estado São Paulo 1: 44. 1939.

Figure $2 \mathrm{f}$

This epiphyte differs from Campylocentrum micranthum by its coriaceous, oblong leaves, flowers with a slightly curved spur and unribbed fruit. It occurs in forested areas and it is endemic to Brazil (States of Ceará, Rio Grande do Norte, Paraíba, Pernambuco, Alagoas, Sergipe, Bahia, Minas Gerais, Espírito Santo, Rio de Janeiro, São Paulo, Paraná, Santa Catarina and Mato Grosso do Sul) (Barros et al. 2014, Govaerts et al. 2014).

Examined material: BRAZIL. Pernambuco: Jaqueira, RPPN Frei Caneca, 11-III-2011, fl., E. Pessoa et al. 519 (RB, UFP); 28-I-2013, fr., E. Pessoa et al. 1044 (RB, UFP); Lagoa dos Gatos, RPPN Pedra D'Anta, 18-XII-2010, fr., E.Pessoa et al. 470 (RB, UFP).

11. Campylocentrum micranthum (Lindl.) Rolfe, Orchid Rev. 9: 136. 1903 EAngraecum micranthum Lindl., Edwards's Bot. Reg. 21: t. 1772. 1835.

Figure $2 g$

This epiphyte differs from Campylocentrum crassirhizum by its sub-coriaceous, oblong-elliptical leaves, flowers with a strongly curved spur and 6-ribbed fruit. It occurs in forested areas and it is widely distributed in the Neotropics (Govaerts et al. 2014). In Brazil, it occurs in the Amazon and Atlantic Forests (States of Acre, Amazonas, Roraima, Pará, Amapá, Rondônia, Tocantins, Maranhão, Ceará, Pernambuco, Alagoas, Sergipe, Bahia, Mato Grosso and Goiás) (Barros et al. 2014).

Examined material: BRAZIL. Pernambuco: Jaqueira, RPPN Frei Caneca, 30-V-2012, fl., E. Pessoa et al. 952 (RB, UFP); 31-I-2013, fr., E. Pessoa et al. 1062 (RB, UFP). 

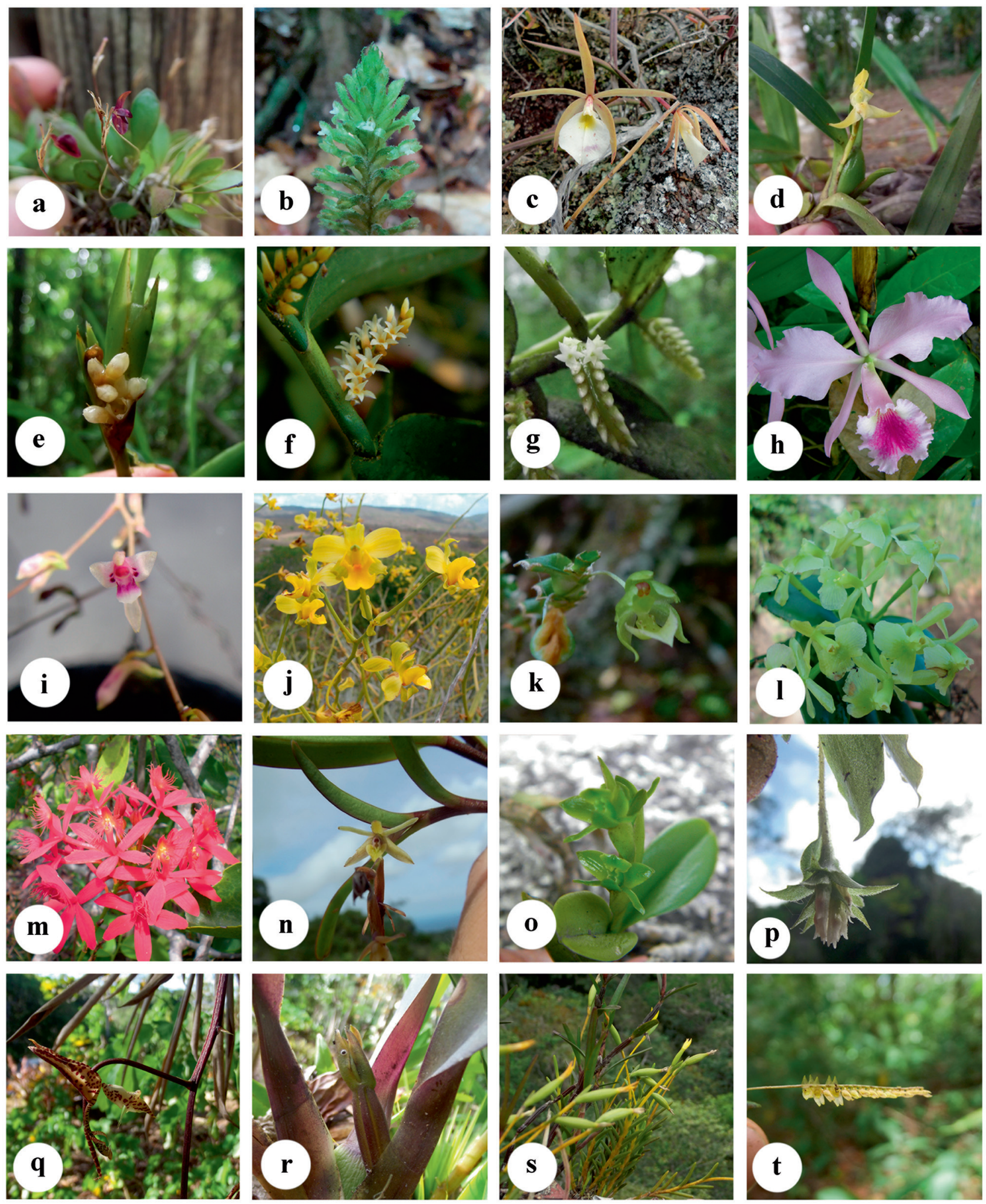

Figure 2: a. Anathallis barbulata. b. Aspidogyne foliosa. c. Brassavola tuberculata. d. Camaridium carinatum. e. Camaridium micranthum. f. Campylocentrum crassirhizum. g. Campylocentrum micranthum. h. Cattleya labiata. i. Comparettia barkeri. j. Cyrtopodium flavum. k. Dichaea panamensis. 1. Epidendrum campaccii. m. Epidendrum cinnabarinum. n. Epidendrum ramosum. o. Epidendrum rigidum. p. Eurystyles cotyledon. q. Gongora vitorinoana. r. Heterotaxis discolor. s. Jacquiniella teretifolia. t. Lepanthopsis floripectren. 
12. Campylocentrum pernambucense Hoehne, Arq.

Bot. Estado São Paulo 1: 22. 1938.

Figure 1e

This epiphyte is easily recognized among the species of the genus in the area by its cylindrical leaves and shorter inflorescence $(<0.8 \mathrm{~cm}$ long). It occurs in forested areas and it is endemic to the Atlantic Forest of northeastern Brazil (States of Paraiba, Pernambuco, Alagoas and Sergipe) (Barros et al. 2014, Govaerts et al. 2014). It is cited as endangered by the Ministério do Meio Ambiente (2008) and Martinelli \& Moraes (2013). There are large populations of this species in the Serra do Urubu.

Examined material: BRAZIL. Pernambuco: Jaqueira, RPPN Frei Caneca, 31-V-2012, fl. e fr., E. Pessoa et al. 960 (RB, UFP); 29-I-2013, fr., E. Pessoa et al. 1050 (RB, UFP); Lagoa dos Gatos, RPPN Pedra D'Anta, 17-XII-2010, fl. e fr., E.Pessoa et al. 429 (RB, UFP).

13. Cattleya granulosa Lindl., Edwards's Bot. Reg. 28: t. 1.1842.

Figure 1f

This epiphyte differs from Cattleya labiata by the 2-leaved, cylindrical pseudobulbs and sepals greenish to yellowish with brown spots. It occurs in forested areas and it is endemic to the Brazilian Atlantic Forest (States of Rio Grande do Norte, Paraíba, Pernambuco, Alagoas, Bahia and Espírito Santo) (Barros et al. 2014, Govaerts et al. 2014). It is cited as endangered by the Ministério do Biodiversitas (2008), Meio Ambiente (2008) and Martinelli \& Moraes (2013). It is rarely found in the Serra do Urubu.

Examined material: BRAZIL. Pernambuco: Jaqueira, RPPN Frei Caneca, 30-V-2012, fl., E. Pessoa et al. 941 (UFP).

14. Cattleya labiata Lindl., Coll. Bot. t. 33. 1824. Figure $2 \mathrm{~h}$

This epiphyte differs from Cattleya granulosa by its 1-leaf, fusiform pseudobulbs and flowers with pinkish sepals. It occurs in forested areas and it is endemic to the Brazilian Atlantic Forest (States of Ceará, Paraíba, Pernambuco, Alagoas, Sergipe, Espírito Santo and Rio de Janeiro) (Barros et al. 2014, Govaerts et al. 2014). It is cited as endangered by the Ministério do Biodiversitas (2008), Meio Ambiente (2008) and Martinelli \& Moraes (2013). There are small populations of this species in the Serra do Urubu.
Examined material: BRAZIL. Pernambuco: Jaqueira, RPPN Frei Caneca, 10-III-2011, fl., E. Pessoa et al. 500 (UFP).

15. Comparettia barkeri (Lindl.) M.W.Chase \& N.H.Williams, Lindleyana 21(3): 27. $2008 \equiv$ Chaenanthe barkeri Lindl., Edwards's Bot. Reg. 24: 38. 1838.

\section{Figure 2i}

This epiphyte is easily recognized in the area by its dark purple leaves, panicullate inflorescence and flowers with spur. It occurs in forested areas, and it is known from Venezuela to Peru and Brazil, where it has an Atlantic-Amazon disjunction, and it is cited to the States of Pará and Pernambuco (Barros et al. 2014, Govaerts et al. 2014).

Examined material: BRAZIL. Pernambuco: Jaqueira, RPPN Frei Caneca, 31-I-2013, fl., E. Pessoa et al. 1066 (UFP); 17-XII-2010, fl., E. Pessoa et al. 450 (UFP).

16. Cyrtopodium flavum (Nees) Link \& Otto ex Rchb., Iconogr. Bot. Exot. 3: 7. $1830 \equiv$ Tylochilus flavus Nees, Verh. Vereins Beförd. Gartenbaues Königl. Preuss. Staaten 8: 195. 1832.

Figure $2 \mathrm{j}$

This terrestrial or rupiculous herb is easily recognized by the leaves distributed in homoblastic pseudobulbs, and panicullate inflorescence with yellow flowers. It occurs on rock outcrops and it is endemic to Brazil (States of Paraíba, Pernambuco, Alagoas, Sergipe, Bahia, Minas Gerais, Espírito Santo, Rio de Janeiro, São Paulo, Paraná, Santa Catarina and Rio Grande do Sul) (Barros et al. 2014, Govaerts et al. 2014).

Examined material: BRAZIL. Pernambuco: Jaqueira, RPPN Frei Caneca, 10-III-2010, fr., E. Pessoa et al. 458 (UFP); Lagoa dos Gatos, RPPN Pedra D’Anta, 17-XII-2010, fl., E. Pessoa et al. 434 (UFP).

17. Dichaea panamensis Lindl., Gen. Sp. Orchid. Pl. 209. 1833.

Figure 2k

This epiphyte differs from Dichaea pendula by its articulated linear-oblong leaves, and non-geniculated peduncle of the inflorescence. It occurs in forested areas and it is widely distributed in the Neotropics (Govaerts et al. 2014). In Brazil, it has a disjunct distribution between the Amazon and Atlantic Forests 
(States of Amazonas, Pará, Amapá, Rondônia, Mato Grosso, Paraíba, Pernambuco, Alagoas and Sergipe) (Barros et al. 2014).

Examined material: BRAZIL. Pernambuco: Jaqueira, RPPN Frei Caneca, 11-III-2011, fl., E. Pessoa et al. 516 (UFP); Lagoa dos Gatos, 17-XII-2010, fl., E. Pessoa et al. 419 (NY, RB, UFP).

18. Dichaea pendula (Aubl.) Cogn., Symb. Antill. 4: $182.1903 \equiv$ Limodorum pendulum Aubl., Hist. P1. Guiane 2: 8191775.

Figure 1g

This epiphyte differs from Dichaea panamensis by its lack of articulated, elliptical leaves, and genicuted peduncle of the inflorescence. It occurs in forested areas and it is widely distributed in the Neotropics (Govaerts et al. 2014). In Brazil, it has a disjunct distribution between the Amazon and Atlantic Forests (States of Amazonas, Roraima, Ceará, Paraíba, Espírito Santo, Rio de Janeiro, São Paulo, Paraná, Santa Catarina and Rio Grande do Sul) (Barros et al. 2014). It is a new record for the State of Pernambuco.

Examined material: BRAZIL. Pernambuco: Jaqueira, RPPN Frei Caneca, 31-V-2012, fr., E. Pessoa et al. 958 (UFP); 30-I-2013, fl., E. Pessoa et al. 1055 (NY, RB, UFP); 2-XI-2001, fr. e fl., J.A. Siqueira-Filho 1178 (UFP).

19. Dimerandra emarginata (G.Mey.) Hoehne, Bol. Agric. (São Paulo) 34: 618. 1933 E Oncidium emarginatum G.Mey., Prim. Fl. Esseq.: 259. 1818. Figure $1 \mathrm{~h}$

This epiphyte resembles an Epidendrum, but differs from the species of that genus in the area by its pinkish flowers with the column basally adnate with the lip. It occurs in forested areas and it is widely distributed in the Neotropics (Govaerts et al. 2014). In Brazil, it has a disjunct distribution between the Amazon and Atlantic Forests (States of Amazonas, Amapá, Pará, Maranhão, Ceará, Paraíba, Pernambuco, Alagoas, Sergipe, Bahia and Espírito Santo) (Barros et al. 2014).

Examined material: BRAZIL. Pernambuco: Lagoa dos Gatos, RPPN Pedra D'Anta, 18-XII-2010, fl., E. Pessoa et al. 460 (RB, UFP).

20. Elleanthus linifolius C.Pres1., Reliq. Haenk. 1: 97. 1827.

Figure 1i

This epiphyte can be confused vegetatively in the area with Isochilis linearis but it differs by its floral bracts covering almost entirely the white flowers. It occurs in forested areas and it is widely distributed in the Neotropics (Govaerts et al. 2014). In Brazil, it has a disjunct distribution between the Amazon and Atlantic Forests (States of Amazonas, Amapá, Roraima, Pernambuco, Bahia, Minas Gerais, Espírito Santo, Rio de Janeiro, São Paulo and Paraná) (Barros et al. 2014).

Examined material: Brazil. Pernambuco: Jaqueira, RPPN Frei Caneca, 30-I-2000, fl. e fr., J.A. SiqueiraFilho 1015 (UFP).

21. Epidendrum anatipedium L.M.Sánchez \& Hágsater, Orquídea (Mexico City) 13: 291. 1993. Figure $1 \mathrm{j}$

This epiphyte differs from Epidendrum campaccii by its longer sepals ( $>3.0 \mathrm{~cm}$ long) and entire mid-lobe of the lip. It occurs in forested areas and it is endemic to the Atlantic Forest of northeastern Brazil (Ceará State) (Barros et al. 2014, Govaerts et al. 2014). It is a new record for the State of Pernambuco.

Examined material: BRAZIL. Pernambuco: Jaqueira, RPPN Frei Caneca, 29-V-2012, fl., E. Pessoa et al. 935 (UFP).

22. Epidendrum campaccii Hágsater \& L.Sánchez, Icon. Orchid. 2: t. 117. 1993.

Figure 21

This epiphyte differs from E. anatipedium by its shorter sepals ( $<1.5 \mathrm{~cm}$ long) and 2-lobed mid-lobe of the lip. It occurs in forested areas and it is endemic to Brazil (States of Ceará, Paraíba, Pernambuco, Alagoas, Bahia, Espírito Santo, Rio de Janeiro, São Paulo and Santa Catarina) (Barros et al. 2014, Govaerts et al. 2014).

Examined material: BRAZIL. Pernambuco: Jaqueira, RPPN Frei Caneca, 30-V-2012, fl., E. Pessoa et al. 937 (RB, UFP); 10-III-2011, fl., E. Pessoa et al. 503 (UFP).

23. Epidendrum carpophorum Barb.Rodr., Gen. Sp. Orchid. 2: 148. 1882.

Figure 1k

This epiphyte differs from the other Epidendrum species in the area by its linear mid-lobe of the lip. It occurs in forested areas and rock outcrops, and it is known from Guyana, Suriname, Venezuela and Brazil where it has a disjunct distribution between the Amazon and Atlantic Forests (States of Amazonas, 
Amapá, Pará, Roraima, Ceará, Pernambuco, Alagoas, Bahia, Minas Gerais, Espírito Santo, Rio de Janeiro and São Paulo) (Barros et al. 2014, Govaerts et al. 2014).

Examined material: BRAZIL. Pernambuco: Jaqueira, RPPN Frei Caneca, 29-I-2013, fl. e fr., E. Pessoa et al. 1048 (RB, UFP); Lagoa dos Gatos, 17-XII-2010, fr., E. Pessoa et al. 424 (UFP).

24. Epidendrum cinnabarinum Salzm. ex Lindl., Gen. Sp. Orchid. Pl. 106. 1831.

Figure 2m

It differs from E. macrocarpum by its rupiculous or terrestrial habit and completely fringed lateral lobes of the lip. It occurs on rock outcrops and it is endemic to northeastern Brazil (States of Rio Grande do Norte, Paraíba, Pernambuco, Alagoas, Sergipe and Bahia) (Barros et al. 2014, Govaerts et al. 2014).

Examined material: BRAZIL. Pernambuco: Jaqueira, RPPN Frei Caneca, 28-I-2013, fl., D. Araújo 2444 (UFP); 10-III-2011, fl., E. Pessoa et al. 505 (NY, RB, UFP); 17-XII-2010, fl., E. Pessoa et al. 436 (RB, UFP).

25. Epidendrum macrocarpum Rich., Actes Soc. Hist.

Nat. Paris 1: 112. 1792.

Figure 11

This species differs from E. cinnabarinum by its epiphytic habit and apically serrate lateral lobes of the lip. It occurs in forested areas, and it is known from Trinidad and Tobago, French Guyana, Guyana, Suriname, Venezuela, Colombia, Ecuador, Peru and Brazil (States of Amazonas, Amapá, Pará, Roraima, Maranhão, Paraíba, Pernambuco, Alagoas, Bahia) (Barros et al. 2014, Govaerts et al. 2014).

Examined material: BRAZIL. Pernambuco: Jaqueira, RPPN Frei Caneca, 13-X-2010, fl., A. Melo 588 (UFP).

26. Epidendrum proligerum Barb.Rodr., Gen. Sp. Orchid. 1: 61. 1877.

Figure 1m

The flowers of this epiphyte can be confused in the area with $E$. campaccii, but it differs vegetatively by its branched stem. It occurs in forested areas and it is endemic to the Atlantic Forest of Brazil (States of Pernambuco, Alagoas, Bahia, Espírito Santo, Rio de Janeiro, Minas Gerais, São Paulo, Paraná, Santa Catarina and Rio Grande do Sul) (Barros et al. 2014, Govaerts et al. 2014).
Examined material: BRAZIL. Pernambuco: Jaqueira, RPPN Frei Caneca, 1-VII-1986, fl., J.G. Gomes s.n. (UFP).

27. Epidendrum ramosum Jacq., Enum. Syst. P1. 29. 1760.

Figure 2n

This epiphyte differs from E. strobiliferum by its linear-oblong leaves and linear petals. It occurs in forested areas and it is widely distributed in the Neotropics (Govaerts et al. 2014). In Brazil, it has a disjunct distribution between the Amazon and Atlantic Forests (States of Amazonas, Amapá, Roraima, Ceará, Pernambuco, Bahia, Rio de Janeiro, Minas Gerais, Espírito Santo, São Paulo, Paraná, Santa Catarina and Rio Grande do Sul) (Barros et al. 2014).

Examined material: BRAZIL. Pernambuco: Jaqueira, RPPN Frei Caneca, 21-IX-2011, fr., B.S. Amorim 1128 (UFP); Lagoa dos Gatos, RPPN Pedra D’Anta, 16-XII-2010, fl., E. Pessoa et al. 414 (RB, UFP).

28. Epidendrum rigidum Jacq., Enum. Syst. P1.: 29. 1760.

Figure $2 \mathrm{O}$

This epiphyte or rupicolous herb differs from such species as E. ramosum, E. strobiliferum which also have floral bracts completely or partially covering the pedicellate ovary, by its non-branched stems and greenish flowers. It occurs in forested areas and on rock outcrops and it is widely distributed in the Neotropics, including Brazil (Barros et al. 2014, Govaerts et al. 2014).

Examined material: BRAZIL. Pernambuco: Jaqueira, RPPN Frei Caneca, 21-IX-2011, fl., B.S. Amorim 1127 (UFP); 19-IX-2011, fl., B.S. Amorim 1063 (UFP); 10-III-2011, fl. e fr., E. Pessoa et al. 506(UFP); Lagoa dos Gatos, RPPN Pedra D'Anta, 17-XII-2010, fr., E. Pessoa et al. 417 (RB, UFP).

29. Epidendrum strobiliferum Rchb.f., Ned. Kruidk. Arch. 4: 333. 1859.

Figure 1n

This epiphyte differs from E. ramosum by its lanceolate to elliptical leaves and oblanceolate petals. It occurs in forested areas and it is widely distributed in the Neotropics (Govaerts et al. 2014). In Brazil, it has a disjunct distribution between the Amazon and Atlantic Forests (States of Acre, Amazonas, Amapá, Pará, Roraima, Rondônia, Mato Grosso, Goiás, 
Maranhão, Pernambuco, Alagoas, Minas Gerais, São Paulo and Paraná) (Barros et al. 2014).

Examined material: BRAZIL. Pernambuco: Lagoa dos Gatos, RPPN Pedra D'Anta, 17-XII-2010, fl., E. Pessoa et al. 420 (NY, RB, UFP).

30. Epidendrum tridactylum Lindl., Edwards's Bot. Reg. 24: 46. 1838.

Figure 10

This epiphyte differs from the other Epidendrum species in the area by its paniculate inflorescence. It occurs in forested areas, and it is known from Ecuador, Peru, Bolivia and Brazil (States of Paraíba, Pernambuco, Bahia, Minas Gerais, Espírito Santo, Rio de Janeiro, São Paulo, Paraná, Santa Catarina and Rio Grande do Sul) (Barros et al. 2014, Govaerts et al. 2014).

Examined material: BRAZIL. PernAmbuco: Jaqueira, RPPN Frei Caneca, 30-V-2012, fl., E. Pessoa et al. 951 (UFP); 17-VII-2002, fl., J.A.Siqueira-Filho 1246 (UFP).

31. Eurystyles cotyledon Wawra, Oesterr. Bot. Z. 13: 223. 1863.

Figure $2 p$

It is easily recognized among the species with leaves disposed in basal rosettes by its epiphytic habit and pendulous inflorescence. It occurs in forested areas, and it is known from Costa Rica, El Salvador, Venezuela, Colombia, Ecuador, Peru, Bolivia and Brazil (States of Pernambuco, Minas Gerais, Espírito Santo, Rio de Janeiro, São Paulo, Paraná, Santa Catarina and Rio Grande do Sul) (Barros et al. 2014, Govaerts et al. 2014).

Examined material: BRAZIL. Pernambuco: Jaqueira, RPPN Frei Caneca, 30-V-2012, fl. E. Pessoa et al. 955 (NY, RB, UFP); 8-X-2000, fl., J.A.Siqueira-Filho 1094 (UFP).

32. Gomesa barbata (Lind1.) M.W.Chase \& N.H.Williams, Ann. Bot. (Oxford) 104: 395. $2009 \equiv$ Oncidium barbatum Lindl. Coll. Bot. t. 27. 1821 Figure 1p

This epiphyte differs from $G$. hookeri by its midlobe of the lip shorter than the lateral lobes, and ciliate lip margin. It occurs in forested areas, and it is known from Bolivia and the Atlantic Forest of Brazil (States of Ceará, Rio Grande do Norte, Paraíba, Pernambuco, Alagoas, Sergipe, Bahia and Minas Gerais) (Barros et al. 2014, Govaerts et al. 2014).
Examined material: BRAZIL. Pernambuco: Lagoa dos Gatos, RPPN Pedra D’Anta, 17-XII-2010, fl., E. Pessoa et al. 415 (UFP).

33. Gomesa hookeri (Rolfe) M.W.Chase \& N.H.Williams, Ann. Bot. (Oxford) 104: $397.2009 \equiv$ Oncidium hookeri Rolfe, Gard. Chron. Ser. 3: 520. 1887.

Figure 1q

This epiphyte differs from G. barbata by its mid-lobe of the lip longer than the lateral lobes, and entire lip margin. It occurs in forested areas and it is endemic to the Brazilian Atlantic Forest (States of Pernambuco, Bahia, Minas Gerais, Rio de Janeiro, São Paulo, Paraná, Rio Grande do Sul) (Barros et al. 2014, Govaerts et al. 2014).

Examined material: BRAZIL. PernAmbuco: Jaqueira, RPPN Frei Caneca, 2-XI-2001, fl., J.A. Siqueira-Filho 1180 (UFP).

34. Gongora vitorinoana Chiron \& L.C.Menezes, Richardiana 8: 38. 2008.

Figure $2 \mathrm{q}$

This epiphyte is easily recognized from other species by its longitudinally multi-sulcate pseudobulbs, and plicate leaves. It occurs in forested areas and it is endemic to the Atlantic Forest of the State of Pernambuco (Barros et al. 2014).

Examined material: BRAZIL. Pernambuco: Jaqueira, RPPN Frei Caneca, 28-I-2013, fl., E. Pessoa et al. 1040 (UFP); 22-V-2000, fl., J.A.Siqueira-Filho 1086 (UFP); Lagoa dos Gatos, RPPN Pedra D’Anta, 16-XII-2010, fl., E. Pessoa et al. 413 (UFP).

35. Habenaria cryptophila Barb. Rodr., Gen. Sp.

Orchid. 1: 154. 1877.

Figure 1r

This terrestrial herb differs from species such as $H$. pratensis and $H$. trifida, which also have 2-lobed petals and a 3-lobed lip, by its ovate sepals and anterior lobe of the lip longer than the posterior one. It occurs on rock outcrops and it is endemic to Brazil (States of Paraíba, Pernambuco Bahia, Distrito Federal, Goiás, Minas Gerais, and São Paulo) (Barros et al. 2014, Govaerts et al. 2014).

Examined material: BRAZIL. Pernambuco: Jaqueira, RPPN Frei Caneca, 3-IX-2013, fl., A. Melo 1197 (UFP). 
36. Habenaria petalodes Lindl., Gen. Sp. Orchid P1. 316. 1835.

Figure 1s

This terrestrial herb differs from the other Habenaria species found in the area by its entire petals and lip. It occurs on rock outcrops and it is known from Argentina, Paraguay and Brazil, where it is widely distributed (Barros et al. 2014, Govaerts et al. 2014).

Examined material: BRAZIL. PernAmbuco: Jaqueira, RPPN Frei Caneca, 17-VIII-2010, fl., M.A. Chagas 19 (UFP).

37. Habenaria pratensis (Lind1.) Rchb.f., Linnaea 22: $813.1850 \equiv$ Bonatea pratensis Lindl., Gen. Sp. Orchid. P1. 328. 1835.

Figure 1t

This terrestrial herb differs from $H$. trifida by its posterior lobe of the petals elliptical, mid-lobe of the lip rhomboid, and shorter spur $(\leq 3.0 \mathrm{~cm}$ long $)$. It occurs on rock outcrops and it is endemic to Brazil (States of Maranhão, Rio Grande do Norte, Paraíba, Pernambuco, Sergipe, Alagoas, Bahia, Mato Grosso, Goiás and Santa Catarina) (Barros et al. 2014, Govaerts et al. 2014).

Examined material: BRAZIL. Pernambuco: Jaqueira, RPPN Frei Caneca, 17-VIII-2010, fl., M.A. Chagas 20 (UFP).

38. Habenaria trifida Kunth, Nov. Gen. Sp. 1: 330. 1816.

Figure $3 \mathrm{a}$

This terrestrial herb differs from $H$. pratensis by its posterior lobe of the petals oblong to linear, mid-lobe of the lip linear-oblong, and longer spur $(>3.0 \mathrm{~cm}$ long). It occurs on rock outcrops and it is widely distributed in the Neotropics and also in Brazil (Barros et al. 2014, Govaerts et al. 2014).

Examined material: BRAZIL. Pernambuco: Lagoa dos Gatos, RPPN Pedra D'Anta, 7-VI-2011, fl., J.L. Viana 295 (JPB).

39. Heterotaxis discolor (Lodd. ex Lindl.) Ojeda \& Carnevali, Novon 15:580.2005 $\equiv$ Dicrypta discolor Lodd. ex Lindl., Edwards's Bot. Reg. 25(Misc.): 91. 1839

Figure 2r

This epiphyte differs from Nitidobulbon nasutum by its discolorous leaves and shorter acute sepals $(<2.0 \mathrm{~cm}$ long). It occurs in forested areas, and it is known from Belize, Nicaragua, French Guyana, Guyana, Suriname, Venezuela, Ecuador, Peru, Bolivia and Brazil (States of Amazonas, Amapá, Pará, Roraima and Bahia) (Barros et al. 2014, Govaerts et al. 2014). It is a new record for the State of Pernambuco and another case of disjunction between the Amazon and Atlantic Forests.

Examined material: BRAZIL. Pernambuco: Jaqueira, RPPN Frei Caneca, 29-V-2012, fl. e fr., E. Pessoa et al. 926 (NY, RB, UFP); 27-VI-1999, J.A.Siqueira-Filho \& J.A.Vicente 955 (UFP).

40. Isochilus linearis (Jacq.) R.Br., Hortus Kew. 5: 209. 1813 E Epidendrum lineare Jacq., Enum. Syst. P1.: 29. 1760.

Figure $3 b$

This epiphyte can be confused vegetatively in the area with E. linifolius, but it differs by its floral bracts covering only the base of the pedicellate ovary, and pinkish flowers. It occurs in forested areas, and it is widely distributed in the Neotropics (Govaerts et al. 2014), including Brazil (States of Ceará, Pernambuco, Bahia, Distrito Federal, Mato Grosso do Sul, Minas Gerais, Espírito Santo, Rio de Janeiro, São Paulo, Paraná, Santa Catarina and Rio Grande do Sul ) (Barros et al. 2014).

Examined material: BRAZIL. Pernambuco: Jaqueira, RPPN Frei Caneca, 30 -V- 2012, fl., E. Pessoa et al. 949 (NY, RB, UFP); 9-VII-1999, fr., J.A. SiqueiraFilho \& J.A. Vicente 981 (UFP); 11-III-2011, fr., E. Pessoa et al. 538 (NY, RB, UFP).

41. Jacquiniella globosa (Jacq.) Schltr., Repert. Spec. Nov. Regni Veg. Beih. 7: 124. 1920 E Epidendrum globosum Jacq., Enum. Syst. P1.: 29. 1760.

Figure 3c

This epiphyte differs from $J$. teretifolia by its sessile inflorescence and purple flowers. It occurs in forested areas and it is widely distributed in the Neotropics (Govaerts et al. 2014); in Brazil, it is found in the Amazon and Atlantic Forests (States of Amazonas, Pará, Roraima, Ceará, Pernambuco, Alagoas, Sergipe, Bahia, Espírito Santo, Rio de Janeiro, São Paulo, Paraná and Santa Catarina) (Barros et al. 2014).

Examined material: BRAZIL. Pernambuco: Jaqueira, RPPN Frei Caneca, 29-I-2013, fl., D. Araújo 2385 (UFP); 10-III-2011, fr., E. Pessoa et al. 507 (RB, UFP); 17-VIII-2010, fl., A. Melo 447 (UFP); 


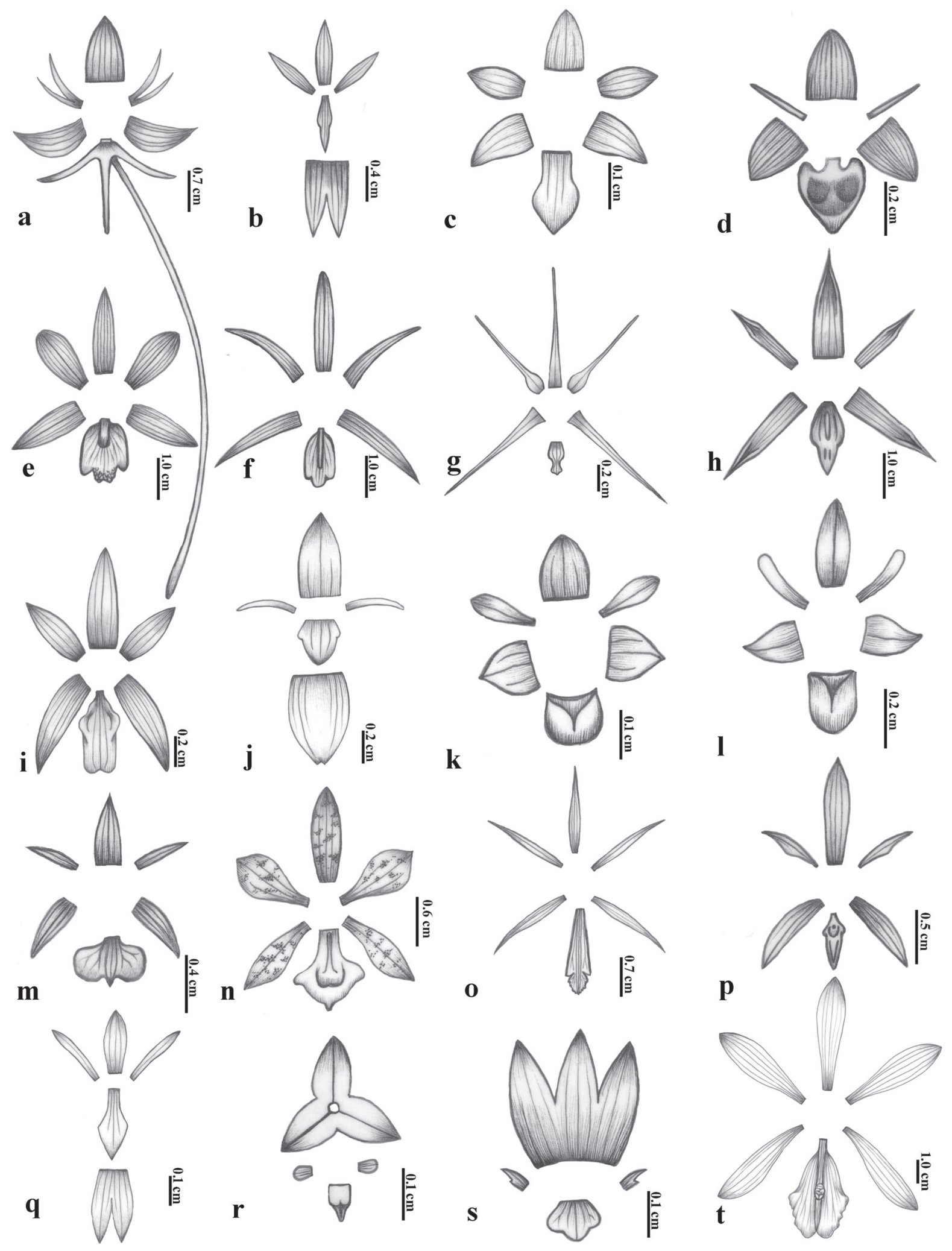

Figure 3: a. Habenaria trifida. b. Isochillus linearis. c. Jacquiniella globosa. d. Malaxis excavata. e. Mapinguari desvauxianus. f. Maxillaria leucaimata. g. Myoxanthus exasperatus. h. Nitidobulbon nasutum. i. Octomeria alexandrii. j. Pleurothallis pruinosa. k. Prescottia oligantha. 1. Prescottia plantaginifolia. m. Prosthechea pygmaea. n. Prosthechea vespa. o. Psilochilus modestus. p. Rhetinantha notylioglossa. q. Scaphyglottis sickii. r. Stelis aprica. s. Stelis deregularis. t. Vanilla cf. pompona. 
21-IX-2011, fl., B.S. Amorim 1129 (UFP); Lagoa dos Gatos, RPPN Pedra D'Anta, 17-XII-2010, fl., E. Pessoa et al. 423 (NY, RB, UFP).

42. Jacquiniella teretifolia (Sw.) Britton \& P.Wilson, Sci. Surv. Porto Rico \& Virgin Islands 6:340. 1926 Epidendrum teretifolium Sw., Prodr. Veg. Ind. Occ.: 122. 1788

Figure $2 \mathrm{~s}$

This epiphyte differs from $J$. globosa by its longpedunculate inflorescence and yellowish to orangish flowers. It occurs in forested areas and it is widely distributed in the Neotropics (Govaerts et al. 2014); in Brazil, it is found in the Amazon and Atlantic Forests (States of Amazonas, Roraima, Bahia, Minas Gerais, Espírito Santo, Rio de Janeiro and São Paulo) (Barros et al. 2014). It is a new record for the State of Pernambuco.

Examined material: BRAZIL. Pernambuco: Jaqueira, RPPN Frei Caneca, 30-V-2012, fr., E. Pessoa 950 (RB, UFP); 29-I-2013, fl. e fr., E. Pessoa et al. 1053 (UFP).

43. Lepanthopsis floripecten (Rchb.f.) Ames, Bot. Mus. Leafl. 1: 11. $1933 \equiv$ Pleurothallis floripecten Rchb.f., Bonplandia (Hannover) 2: 25. 1854.

Figure $2 \mathrm{t}$

This epiphyte is easily distinguished from the other Pleurothallidinae in the area by its lepanthiform sheaths. It occurs in forested areas and it is widely distributed in the Neotropics (Govaerts et al. 2014); in Brazil, it grows in the Amazon and Atlantic Forests (States of Pernambuco, Espírito Santo, Rio de Janeiro, São Paulo, Paraná and Santa Catarina) (Barros et al. 2014).

Examined material: BRAZIL. Pernambuco: Jaqueira, RPPN Frei Caneca, 30-V-2012, fl. e fr., E. Pessoa et al. 940 (UFP); 29-I-2013, fl., E. Pessoa et al. 1049 (UFP).

44. Liparis nervosa (Thunb.) Lindl., Gen. Sp. Orchid Pl.: 26. $1830 \equiv$ Ophrys nervosa Thunb., Syst. Veg., ed. 14: 814. 1784.

Figure $4 \mathrm{a}$

This terrestrial herb can be confused vegetatively in the area with Malaxis excavata, but can be easily recognized by its racemose inflorescence and 2-lobed lip. It occurs in forested areas and it is pantropical and widely distributed in Brazil (Barros et al. 2014, Govaerts et al. 2014).

Examined material: BRAZIL. Pernambuco: Jaqueira, RPPN Frei Caneca, 21-V-2000, fl., J.A. Siqueira-Filho 1085 (UFP).
45. Malaxis excavata (Lindl.) Kuntze, Revis. Gen. P1. 2: 673. 1891 E Microstylis excavata Lindl., Edwards's Bot. Reg. 24: 51. 1838.

Figure 3d

This terrestrial herb can be confused vegetatively in the area with Liparis nervosa, but it can be easily recognized by its umbellate inflorescence and acute lip. It occurs in forested areas and it is widely distributed in the Neotropics (Govaerts et al. 2014), including Brazil (States of Bahia, Distrito Federal, Minas Gerais, Espírito Santo, Rio de Janeiro, São Paulo, Paraná, Santa Catarina and Rio Grande do Sul) (Barros et al. 2014). It is a new record for the State of Pernambuco.

Examined material: BRAZIL. Pernambuco: Lagoa dos Gatos, RPPN Pedra D'Anta, 7-VI-2011, fl., J.L. Viana 307 (JPB); 22-XI-2011, fl., J.L. Viana 365 (JPB).

46. Mapinguari desvauxianus (Rchb.f.) Carnevali \& R.B.Singer, Lankesteriana 7:525.2007 = Maxillaria desvauxiana Rchb.f., Bonplandia (Hannover) 3: 67. 1854.

Figure 3e

This epiphyte differs from Mormolyca rufescens by its pseudo-petiolate leaves and papillose mid-lobe of the lip. It occurs in forested areas and it is known from French Guyana, Guyana, Suriname, Venezuela, Colombia, Ecuador, Peru and Brazil (States of Amazonas, Pará, Bahia, Espírito Santo, Rio de Janeiro, São Paulo, Paraná and Santa Catarina) (Barros et al. 2014, Govaerts et al. 2014). It is a new record for the State of Pernambuco.

Examined material: BRAZIL. Pernambuco: Jaqueira, RPPN Frei Caneca, 29-V-2012, fl., E. Pessoa et al. 930 (UFP); 9-VII-1999, fl., J.A.Siqueira-Filho \& J.A. Vicente 979 (UFP).

47. Maxillaria leucaimata Barb. Rodr., Gen. Sp. Orchid. 2: 198. 1882.

Figure $3 \mathrm{f}$

This epiphyte can be confused in the area with Mormolyca rufescens and Mapinguari desvauxianus, but it differs by its inflorescences twice as long as the length of the pseudobulb. It occurs in forested areas, and it is known from French Guyana and Brazil (States of Amazonas, Pará, Ceará, Minas Gerais, Espírito Santo, Rio de Janeiro, São Paulo, Paraná and Santa Catarina) (Barros et al. 2014, Govaerts et al. 2014). It is a new record for the State of Pernambuco. 
Examined material: BRAZIL. Pernambuco: Jaqueira, RPPN Frei Caneca, 29-I-2013, fl. e fr., E. Pessoa et al. 1054 (RB, UFP); 21-IX-2011, fl., B.S. Amorim 1125 (UFP); Lagoa dos Gatos, RPPN Pedra D’Anta, 19-XII-2010, fr., E. Pessoa et al. 479 (UFP).

48. Maxillaria ochroleuca Lodd. ex Lindl., Gen. Sp.

Orchid. Pl. 143. 1832.

Figure $4 \mathrm{~b}$

This epiphyte differs from Camaridium carinatum by its pseudo-petiolate apical leaf, withish flowers and longer sepals ( $>3.5 \mathrm{~cm}$ long). It occurs in forested areas and it is known from Venezuela, Colombia, Ecuador, Peru and Brazil (States of Roraima, Pernambuco, Bahia, Espírito Santo, Rio de Janeiro, Minas Gerais, São Paulo, Paraná and Santa Catarina) (Barros et al. 2014, Govaerts et al. 2014).

Examined material: BRAZIL. Pernambuco: Jaqueira, RPPN Frei Caneca, 29-V-2012, fl. e fr., E. Pessoa et al. 927 (UFP); 27-VI-1999, fl., J.A.Siqueira-Filho 957 (UFP); 19-VII-2012, fl., J.L. Costa-Lima 754 (UFP).

49. Mesadenella cuspidata (Lindl.) Garay, F1. Ecuador 9:238. 1978 $\equiv$ Spiranthes cuspidata Lindl., Gen. Sp. Orchid. P1.: 471. 1840.

Figure $4 \mathrm{c}$

This terrestrial herb differs from Sacoila lanceolata by having leaves when in bloom and by the yellowish-white flowers. It occurs in forested areas and it is known from Guyana, Suriname, Venezuela, Colombia, Ecuador, Peru, Bolivia, Paraguay, Argentina and Brazil (States of Mato Grosso, Goiás, Distrito Federal, Espírito Santo, Rio de Janeiro, Minas Gerais, São Paulo, Paraná, Santa Catarina and Rio Grande do Sul) (Barros et al. 2014, Govaerts et al. 2014). It is a new record for the State of Pernambuco.

Examined material: BRAZIL. Pernambuco: Jaqueira, RPPN Frei Caneca, 30-V-2012, fl., E. Pessoa et al. 957 (RB, UFP); 30-VI-2011, fl., D.S. Corrêa 105 (UFP).

50. Mormolyca rufescens (Lind1.) M.A.Blanco, Lankesteriana 7: 531.2007 $\equiv$ Maxillaria rufescens Lindl., Edwards's Bot. Reg. 22: t. 1848. 1836. Figure $4 d$

This epiphyte differs from Mapinguari desvauxianus by its sub-sessile leaves and smooth, not papillose mid-lobe of the lip. It occurs in forested areas, and it is known from Belize, Guatemala, Honduras, Trinidad and Tobago, French Guyana, Guyana, Suriname, Venezuela, Colombia, Ecuador,
Peru and Brazil, where it is widely distributed (Barros et al. 2014, Govaerts et al. 2014).

Examined material: BRAZIL. PernAmbuco: Jaqueira, RPPN Frei Caneca, 29-V-2012, fl., E. Pessoa et al. 929 (NY, RB, UFP); 11-III-2011, fl., E. Pessoa et al. 547 (UFP).

51. Myoxanthus exasperatus (Lind1.) Luer, Selbyana 7: $36.1982 \equiv$ Pleurothallis exasperata Lindl., Fol. Orchid. 9: 15. 1859.

Figure $3 g$

This epiphyte differs from Pleurothallis ruscifolia by its lateral sepals connate only at base. It occurs in forested areas, and it is known from Costa Rica, El Salvador, Honduras, Panama, Guyana, Suriname, Venezuela, Colombia, Ecuador, Peru and Brazil (States of Pernambuco, Bahia, Espírito Santo, Rio de Janeiro, Minas Gerais, São Paulo, Paraná and Santa Catarina) (Barros et al. 2014, Govaerts et al. 2014).

Examined material: BRAZIL. Pernambuco: Jaqueira, RPPN Frei Caneca, 28-I-2013, fl., E. Pessoa et al. 1042 (UFP); 9-VII-1999, fl., J.A.Siqueira-Filho \& J.A. Vicente 983 (UFP).

52. Nitidobulbon nasutum (Rchb.f.) I.Ojeda \& Carnevali, Novon 19: 99. 2009 Maxillaria nasuta Rchb.f., Beitr. Orchid.-K. C. Amer.: 104. 1866. Figure $3 \mathrm{~h}$

This epiphyte differs from Heterotaxis discolor by its concolorous leaves and longer acuminate sepals ( $\geq 2.5 \mathrm{~cm}$ long). It occurs in forested areas and it is widely distributed in the Neotropics (Govaerts et al. 2014); in Brazil, it is found in the Amazon and Atlantic Forests (States of Amazonas, Roraima, Mato Grosso, Bahia and Espírito Santo) (Barros et al. 2014). It is a new record for the State of Pernambuco. However it was not recollected during this survey.

Examined material: BRAZIL. Pernambuco: Jaqueira, RPPN Frei Caneca, 9-VII-1999, fl., J.A. SiqueiraFilho \& J.A. Vicente 984 (UFP).

53. Notylia inversa Barb. Rodr., Gen. Sp. Orchid. 2: 223. 1882.

Figure $4 \mathrm{e}$

This epiphyte is easily distinguished from the orchids in the area by its pendulous inflorescence and flowers with a clawed lip. It occurs in forested areas and it is endemic to Brazil (States of Ceará and Minas Gerais) (Barros et al. 2014, Govaerts et al. 2014). It is a new record for the State of Pernambuco. 

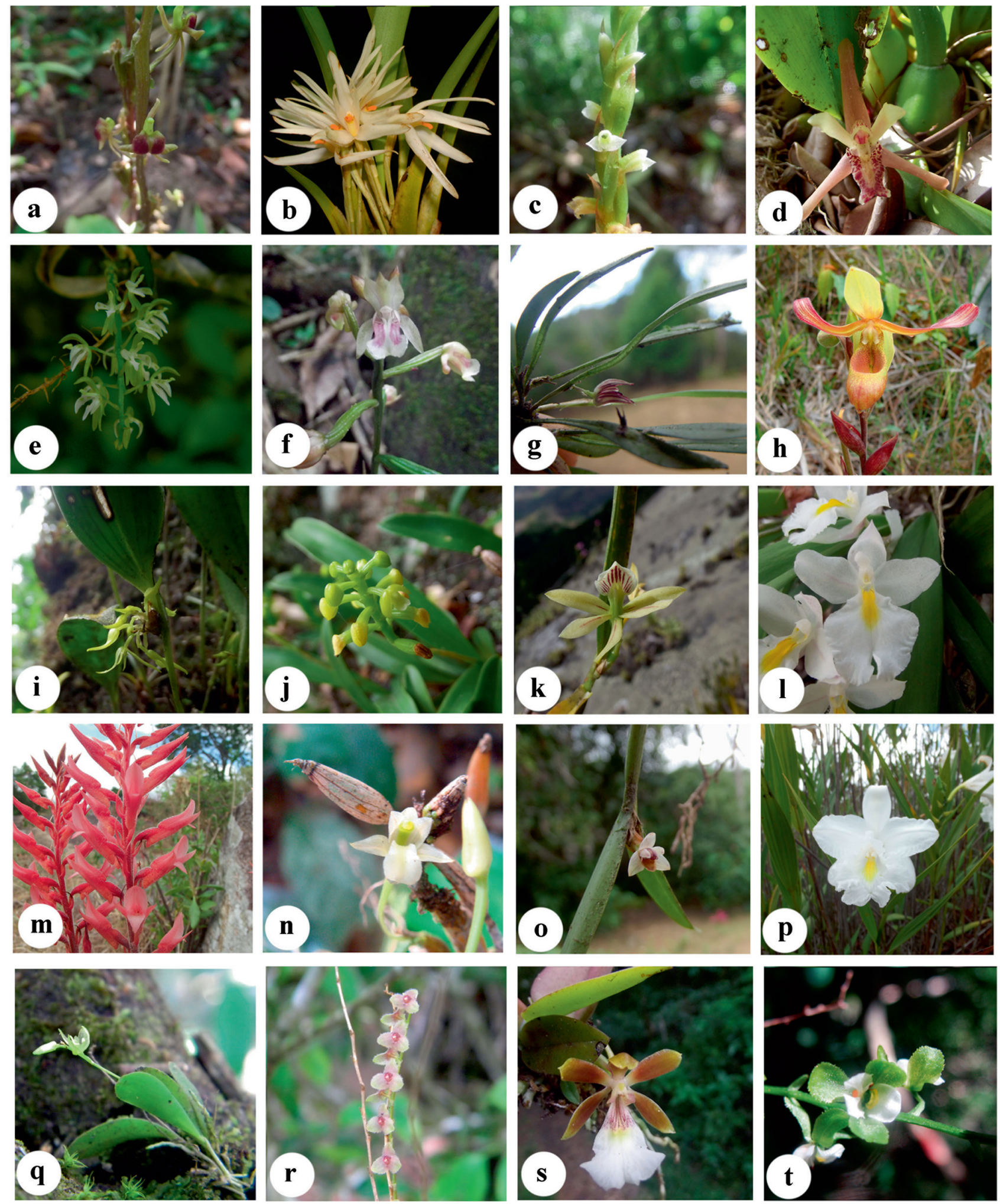

Figure 4: a. Liparis nervosa. b. Maxillaria ochroleuca. c. Mesadenella cuspidata. d. Mormolyca rufescens. e. Notylia inversa. f. Oeceoclades maculata. g. Pabstiella lingua. h. Phragmipedium sargentianum. i. Pleurothallis ruscifolia. j. Polystachya estrellensis. k. Prosthechea alagoensis. 1. Rodriguezia bahiensis. m. Sacoila lanceolata. n. Scaphyglottis fusiformis. o. Scaphyglottis modesta. p. Sobralia liliastrum. q. Specklinia integripetala. r. Stelis loefgrenii. s. Trichocentrum fuscum. t. Zygostates bradei. 
Examined material: BRAZIL. Pernambuco: Jaqueira, RPPN Frei Caneca, 28-I-2013, fl., E. Pessoa et al. 1042 (UFP); 31-I-2013, fl., E. Pessoa et al. 1067 (UFP); 10-III-2011, fl., E. Pessoa et al. 501 (RB, UFP); Lagoa dos Gatos, RPPN Pedra D'Anta, 19-XII-2010, fl., E. Pessoa et al. 480 (UFP).

54. Octomeria alexandri Schltr., Anexos Mem. Inst. Butantan, Secc. Bot. 1: 53. 1922.

\section{Figure $3 i$}

This rupiculous herb can be confused vegetatively in the area with Brassavola tuberculata, but it is easily distinguished by its congested fascicle and shorter sepals $(<1.0 \mathrm{~cm}$ long). It occurs on rock outcrops and it is endemic of Brazil (States of Bahia, Rio de Janeiro, São Paulo and Rio Grande do Sul) (Barros et al. 2014, Govaerts et al. 2014). It is a new record for the State of Pernambuco. It is cited as endangered by Martinelli \& Moraes (2013).

Examined material: BRAZIL. Pernambuco: Jaqueira, RPPN Frei Caneca, 31-I-2013, fl., E. Pessoa et al. 1065 (UFP); 10-III-2011, st., E. Pessoa et al. 502 (UFP).

55. Oeceoclades maculata (Lindl.) Lindl., Gen. Sp. Orchid. P1.: 237. 1833 E Angraecum maculatum Lindl. Coll. Bot.: t. 15. 1821.

Figure $4 \mathrm{f}$

This terrestrial herb is easily distinguished from other species in the area by its variegated leaves and the apically 2-lobed spur. It occurs in forested areas and it is pantropical and widely distributed in Brazil (Barros et al. 2014, Govaerts et al. 2014).

Examined material: BRAZIL. PeRnAmbuco: Jaqueira, RPPN Frei Caneca, 12-X-2010, fl. e fr., G.A. GomesCosta 1094 (UFP).

56. Pabstiella lingua (Lind1.) Luer, Monogr. Syst. Bot.MissouriBot.Gard. 112: 120.2007 EPleurothallis lingua Lindl., Edwards's Bot. Reg. 28: 80. 1842. Figure 4g

This epiphyte differs from the other Pleurothallidinae in the area by its 1 -flowered inflorescence. It occurs in forested areas and it is endemic to the Brazilian Atlantic Forest (States of Pernambuco, Minas Gerais, Espírito Santo and Rio de Janeiro) (Barros et al. 2014, Govaerts et al. 2014).

Examined material: BRAZIL. PeRnAMBUCO: Jaqueira, RPPN Frei Caneca, 30-V-2012, fl., E. Pessoa et al.
943 (NY, RB, UFP); 11-III-2011, fl., E. Pessoa et al. 522 (RB, UFP).

57. Phragmipedium sargentianum (Rolfe) Rolfe, Orchid Rev. 4: 332. 1896 三 Selenipedium sargentianum Rolfe, Orchid Rev. 1: 239. 1893.

Figure $4 \mathrm{~h}$

This terrestrial herb is easily recognized among the species in the area by its undulated petals, calceolate lip, and a conspicuous shield-like staminode. It occurs on rock outcrops and it is endemic to the Atlantic Forest of northeastern Brazil (States of Pernambuco, Alagoas and Bahia) (Barros et al. 2014, Govaerts et al. 2014). It is cited as endangered by the Ministério do Meio Ambiente (2008) and Biodiversitas (2008). It is rarely found in the Serra do Urubu.

Examined material: BRAZIL. Pernambuco: Lagoa dos Gatos, RPPN Pedra D'Anta, 17-X-2010, fl., E. Pessoa et al. 435 (UFP).

58. Pleurothallis pruinosa Lindl., Edwards's Bot. Reg. 28(Misc.): 75. 1842.

Figure $3 \mathrm{j}$

This epiphyte differs from Acianthera hygrophyla by its shorter sepals $(\leq 0.3 \mathrm{~cm}$ long $)$ and linear petals. It occurs in forested areas and it is known from Costa Rica, Honduras, Panama, Cuba, Dominican Republic, Jamaica, Puerto Rico, Trinidad and Tobago, French Guyana, Guyana, Suriname, Venezuela, Colombia, Ecuador, Peru and Brazil (States of Amazonas, Amapá, Pará, Maranhão and Pernambuco) (Barros et al. 2014, Govaerts et al. 2014).

Examined material: BRAZIL. Pernambuco: Jaqueira, RPPN Frei Caneca, 29-V-2012, fl., E. Pessoa et al. 932 (NY, RB, UFP); 11-III-2011, fl., E. Pessoa et al. 546 (UFP).

59. Pleurothallis ruscifolia (Jacq.) R.Br., Hortus Kew. 5:211. 1813 EEpidendrum ruscifolium Jacq., Enum. Syst. P1.: 29. 1760.

Figure $4 \mathrm{i}$

This epiphyte differs from Myoxanthus exasperatus by its lateral sepals by being completely connate. It occurs in forested areas and it is widely distributed in the Neotropics (Govaerts et al. 2014); in Brazil, it has a disjunct distribution between the Amazon and Atlantic Forests (States of Pará, Roraima and Ceará) (Barros et al. 2014). It is a new record for the State of Pernambuco. 
Examined material: BRAZIL. Pernambuco: Jaqueira, RPPN Frei Caneca, 30-I-2013, fl., E. Pessoa et al. 1057 (UFP).

60. Polystachya estrellensis Rchb.f., Linnaea 25: 231. 1852.

Figure $4 \mathrm{j}$

This epiphyte or rupiculous herb is easily recognized among the species in the area by its homoblastic pseudobulbs with conduplicate leaves, and terminal inflorescence. It occurs in forested areas and on rock outcrops and it is endemic and widely distributed in Brazil (Barros et al. 2014, Govaerts et al. 2014).

Examined material: BRAZIL. Pernambuco: Jaqueira, RPPN Frei Caneca, 30-V-2012, fl., E. Pessoa et al. 939 (UFP, RB); 11-III-2011, fr., E. Pessoa et al. 515 (UFP); Lagoa dos Gatos, RPPN Pedra D’Anta, 17-XII-2010, fr., E. Pessoa et al. 418 (RB, UFP).

61. Prescottia oligantha (Sw.) Lindl., Gen. Sp. Orchid. Pl.: 454. $1840 \equiv$ Cranichis oligantha Sw., Prodr. Veg. Ind. Occ.: 120. 1788.

Figure 3k

This terrestrial herb differs from $P$. plantaginifolia by its shorter $(\leq 4.5 \mathrm{~cm}$ long), ovate to widely elliptical leaves, and whitish flowers. It occurs in forested areas and on rock outcrops and it is widely distributed in the Neotropics (Govaerts et al. 2014), including Brazil (States of Roraima, Pernambuco, Alagoas, Bahia, Goiás, Distrito Federal, Mato Grosso do Sul, Minas Gerais, Espírito Santo, Rio de Janeiro, São Paulo, Paraná, Santa Catarina and Rio Grande do Sul (Barros et al. 2014).

Examined material: BRAZIL. Pernambuco: Lagoa dos Gatos, RPPN Pedra D'Anta, 17-XII-2010, fl. e fr., E. Pessoa et al. 433 (UFP).

62. Prescottia plantaginifolia Lindl. ex Hook., Exot.

Fl.: t. 115. 1824.

Figure 31

This terrestrial herb differs from $P$. oligantha by its longer ( $>5.0 \mathrm{~cm}$ long), lanceolate to elliptical leaves, and greenish flowers. It occurs on rock outcrops and it is endemic to Brazil (States of Rio Grande do Norte, Paraíba, Pernambuco, Alagoas, Sergipe, Bahia, Goiás, Minas Gerais, Espírito Santo, Rio de Janeiro, São Paulo, Paraná and Santa Catarina) (Barros et al. 2014, Govaerts et al. 2014).
Examined material: BRAZIL. Pernambuco: Jaqueira, RPPN Frei Caneca, 17-X-2001, fl., J.A.Siqueira-Filho 1176 (UFP).

63. Prosthechea alagoensis (Pabst) W.E.Higgins, Phytologia 82: 376. 1997 Epidendrum alagoense Pabst, Anais Congr. Soc. Bot. Brasil 14: 18. 1964. Figure 4k

This epiphyte or rupiculous herb differs from $P$. vespa by its longer ( $>0.9 \mathrm{~cm}$ long) and concave lip. It occurs in forested areas and on rock outcrops and it is endemic to the Atlantic Forest of northeastern Brazil (States of Pernambuco and Alagoas) (Barros et al. 2014, Govaerts et al. 2014).

Examined material: BRAZIL. Pernambuco: Jaqueira, RPPN Frei Caneca, 31-I-2013, fl., E. Pessoa et al. 1061 (RB, UFP); 10-III-2011, fl. e fr., E. Pessoa et al. 504 (RB, UFP); 17-XII-2010, fl. e fr., E. Pessoa et al. 426 (UFP).

64. Prosthechea pygmaea (Hook.) W.E.Higgins, Phytologia 82: 380. 1997 EEpidendrum pygmaeum Hook., Bot. Mag. 60: t. 3233. 1833.

Figure $3 \mathrm{~m}$

This epiphyte differs from other Prosthechea species in the area by its long, branched rhizome and 3-lobed lip. It occurs in forested areas and it is widely distributed in the Neotropics (Govaerts et al. 2014), including Brazil (States of Amazonas, Pernambuco, Bahia, Minas Gerais, Espírito Santo, Rio de Janeiro, São Paulo, Paraná, Santa Catarina and Rio Grande do Sul) (Barros et al. 2014).

Examined material: BRAZIL. Pernambuco: Jaqueira, RPPN Frei Caneca, 30-V-2012, fl., E. Pessoa et al. 953 (UFP); Lagoa dos Gatos, RPPN Pedra D'Anta, 17-XII-2010, fr., E. Pessoa et al. 425 (NY, RB, UFP).

65. Prosthechea vespa (Vell.) W.E.Higgins, Phytologia 82: 381. 1997 E Epidendrum vespa Vell., Fl. Flumin. 9: t. 27. 1831.

Figure 3n

This epiphyte differs from $P$. alagoensis by its shorter $(\leq 0.7 \mathrm{~cm}$ long) and convex lip. It occurs in forested areas, and it is known from Costa Rica, French Guyana, Guyana, Suriname, Venezuela, Colombia, Ecuador, Peru, Bolivia and Brazil (States of Acre, Rondônia, Amazonas, Roraima, Pará, Ceará, Pernambuco, Bahia, Goiás, Mato Grosso, Mato Grosso do Sul, Minas Gerais, Espírito Santo, Rio 
de Janeiro, São Paulo, Paraná and Santa Catarina) (Carnevali et al. 2003, Barros et al. 2014).

Examined material: BRAZIL. PernAmbuco: Jaqueira, RPPN Frei Caneca, 20-IX-2011, fl., B.S. Amorim 1087 (UFP).

66. Psilochilus modestus Barb. Rodr., Gen. Sp. Orchid. 2: 273. 1882.

Figure 30

This terrestrial herb is easily recognized among the species in the area by its ovate, conduplicate leaves distributed along the stem, flowers without a spur, and column free. It occurs in forested areas, and it is known from Venezuela and Brazil (States of Amazonas, Bahia, Minas Gerais, Espírito Santo, Rio de Janeiro, São Paulo, Paraná, Santa Catarina and Rio Grande do Sul) (Barros et al. 2014, Govaerts et al. 2014). It is a new record for the State of Pernambuco.

Examined material: Brazil. Pernambuco: Lagoa dos Gatos, RPPN Pedra D'Anta, 9-IX-2010, fl., J.L. Viana 121 (UFP).

67. Rhetinantha notylioglossa (Rchb.f.) M.A.Blanco, Lankesteriana 7: 535. $2007 \equiv$ Maxillaria notylioglossa Rchb.f., Bonplandia (Hannover) 2: 16. 1854.

Figure $3 \mathrm{p}$

This epiphyte is easily recognized among the species in the area by its 2-leaf pseudobulbs and 1 -flowered inflorescence. It occurs in forested areas and it is known from Venezuela, Colombia, Ecuador, Peru, Bolivia and Brazil (States of Roraima, Maranhão, Bahia, Espírito Santo, Rio de Janeiro, Minas Gerais, São Paulo, Paraná, Santa Catarina and Rio Grande do Sul) (Barros et al. 2014, Govaerts et al. 2014). It is a new record for the State of Pernambuco.

Examined material: BRAZIL. PernAmbuco: Jaqueira, RPPN Frei Caneca, 11-III-2011, fl. e fr., E. Pessoa et al. 525 (RB, UFP).

68. Rodriguezia bahiensis Rchb.f., Bonplandia (Hannover) 2: 90. 1854.

Figure 41

This epiphyte is easily distinguished from other species in the area by its lateral inflorescence and white flowers with completely connate lateral sepals. It occurs in forested areas and it is endemic to Brazil (States of Ceará, Paraíba, Pernambuco, Alagoas, Bahia and Minas Gerais) (Barros et al. 2014, Govaerts et al. 2014).
Examined material: BRAZIL. Pernambuco: Jaqueira, RPPN Frei Caneca, 10-III-2011, fl., E. Pessoa et al. 508 (RB, UFP).

69. Sacoila lanceolata (Aubl.) Garay, Bot. Mus. Leafl. 28: $352.1980 \equiv$ Limodorum lanceolatum Aubl., Hist. Pl. Guiane 2: 821. 1775.

Figure $4 \mathrm{~m}$

This terrestrial herb differs from Mesadenella cuspidata by its leafless condition when blooming and the pinkish to magenta flowers. It occurs on rock outcrops and it is widely distributed in the Neotropics, including Brazil (Barros et al. 2014, Govaerts et al. 2014).

Examined material: BRAZIL. Pernambuco: Jaqueira, RPPN Frei Caneca, 28-I-2013, fl., E. Pessoa et al. 1041 (UFP).

70. Scaphyglottis fusiformis (Griseb.) R.E.Schult., Bot. Mus. Leafl. 17: 205. $1957 \equiv$ Hexadesmia fusiformis Griseb., Fl. Brit. W. I.: 623. 1864. Figure 4n

This epiphyte or rupiculous herb differs from the other Scaphyglottis species in the area by its 1-leaf pseudobulb and pedunculate inflorescence. It occurs in forested areas and it is known from Costa Rica, Panama, Trinidad and Tobago, French Guyana, Guyana, Suriname, Venezuela, Colombia, Peru and Brazil (States of Acre, Amazonas, Roraima, Ceará, Pernambuco, Alagoas and Sergipe) (Barros et al. 2014, Govaerts et al. 2014).

Examined material: BRAZIL. PernAmbuco: Jaqueira, RPPN Frei Caneca, 30-I-2013, fl., D. Araújo 2409 (UFP); Lagoa dos Gatos, RPPN Pedra D'Anta, 17-XII-2010, fl., E. Pessoa et al. 422 (RB, UFP); 16-XII-2010, fl., E. Pessoa et al. 412 (UFP).

71. Scaphyglottis modesta (Rchb.f.) Schltr., Repert. Spec. Nov. Regni Veg. 23: 46. 1926 $\equiv$ Tetragamestus modestus Rchb.f., Bonplandia (Hannover) 2: 21. 1854.

Figure 4o

This epiphyte differs from Scaphyglottis sickii by its elliptical sepals, and not-clawed, slightly 3-lobed lip. It occurs in forested areas and it is known from Costa Rica, Panama, Dominican Republic, Puerto Rico, Cuba, Trinidad and Tobago, French Guyana, Guyana, Suriname, Venezuela, Colombia, Ecuador and Brazil, where it is widely distributed (Barros et al. 2014, Govaerts et al. 2014). 
Examined material: BRAZIL. Pernambuco: Jaqueira, RPPN Frei Caneca, 30 -V- 2012, fl., E. Pessoa et al. 963 (UFP); 29-I-2013, fl., E. Pessoa et al. 1045 (UFP); 9-VII-1999, fl. e fr., J.A.Siqueira-Filho \& J.A. Vicente 982 (UFP); 17-VIII-2010, fr., A. Melo 446 (UFP); Lagoa dos Gatos, RPPN Pedra D’Anta, 19-XII-2010, fr., E. Pessoa et al. 481 (RB, UFP).

72. Scaphyglottis sickii Pabst, Orquídea (Rio de Janeiro) 18: 7. 1956.

Figure $3 q$

This epiphyte differs from Scaphyglottis modesta by its linear-oblanceolate sepals, and sub-clawed, entire lip. It occurs in forested areas and it is known from Trinidad and Tobago, French Guyana, Guyana, Suriname, Venezuela, Colombia, Ecuador, Peru and Brazil (States of Amazonas, Roraima, Amapá, Pará, Maranhão, Pernambuco, Alagoas, Sergipe and Mato Grosso) (Barros et al. 2014, Govaerts et al. 2014).

Examined material: BRAZIL. Pernambuco: Jaqueira, RPPN Frei Caneca, 11-III-2011, fl., E. Pessoa et al. 517 (UFP); Lagoa dos Gatos, RPPN Pedra D’Anta, 22-XI-2011, fr., D. Araújo 1893 (UFP); 17-XII-2010, fl., E. Pessoa 421 (RB, UFP).

73. Sobralia liliastrum Lind1., Gen. Sp. Orchid. P1.: 177. 1833.

Figure $4 \mathrm{p}$

This terrestrial or rupiculous herb is easily recognized among the species in the area by its plicate leaves and big white flowers (sepals $>6.0 \mathrm{~cm}$ long). It occurs on rock outcrops and it is known from French Guyana, Guyana, Suriname, Venezuela, Colombia, Peru, Bolivia and Brazil (States of Amazonas, Roraima, Amapá, Pará, Mato Grosso, Pernambuco, Sergipe, Bahia and Espírito Santo) (Barros et al. 2014, Govaerts et al. 2014).

Examined material: BRAZIL. Pernambuco: Jaqueira, RPPN Frei Caneca, 17-VIII-2010, fl., A. Melo 459 (UFP); Lagoa dos Gatos, RPPN Pedra D'Anta, 17-XII-2010, fl., E. Pessoa et al. 432 (RB, UFP).

74. Specklinia integripetala E.Pessoa \& F.Barros, Nordic J. Bot. 32(2): 129. 2014.

Figure $4 \mathrm{q}$

This epiphyte differs from Anathallis sclerophyla by being smaller plants $(<5.0 \mathrm{~cm}$ tall $)$ with shorter sepals ( $<0.4 \mathrm{~cm}$ long). It occurs in forested areas and it is endemic to the Atlantic Forest of Pernambuco (Pessoa et al. 2014a).
Examined material: BRAZIL. Pernambuco: Jaqueira, RPPN Frei Caneca, 17-XII-2010, fl. e fr., E. Pessoa et al. \& A. Melo 428 (NY, RB, SP, UFP); 30-V-2012, fl. e fr., E. Pessoa et al. 944 (UFP).

75. Stelis aprica Lindl., Bot. Mag. 2: 353. 1837.

Figure $3 \mathrm{r}$

This epiphyte differs from Stelis loefgrenii by its narrow, elliptical leaves and lip with acuminate apex. It occurs in forested areas and it is known from Guyana, Suriname, Venezuela, Colombia, Peru, Bolivia and Brazil (States of Pernambuco, Bahia, Espírito Santo, Rio de Janeiro, São Paulo, Paraná and Santa Catarina) (Barros et al. 2014, Govaerts et al. 2014).

Examined material: BRAZIL. Pernambuco: Jaqueira, RPPN Frei Caneca, 11-III-2011, fl., E. Pessoa et al. 545 (UFP).

76. Stelis deregularis Barb. Rodr., Gen. Sp. Orchid. 2: 94.1881

Figure $3 \mathrm{~s}$

This epiphyte differs from the other Stelis species in the area by its sepals connate at base forming a tube. It occurs in forested areas and it is known from Belize, Costa Rica, Honduras, Panama, Ecuador, Peru and Brazil (States of Pernambuco, Alagoas, Bahia, Espírito Santo, Rio de Janeiro, São Paulo, Paraná and Santa Catarina) (Barros et al. 2014, Govaerts et al. 2014).

Examined material: BRAZIL. Pernambuco: Jaqueira, RPPN Frei Caneca, 21-IX-2011, fl. e fr., B.S. Amorim 1126 (UFP); 4-IX-2013, fl., A. Melo 1211 (UFP).

77. Stelis loefgrenii Cogn. in Mart, Fl. Bras. 3: 558 1906.

Figure 4r

This epiphyte differs from Stelis aprica by its widely elliptical to oblanceolate leaves and lip with rounded apex. It occurs in forested areas and it is endemic to Brazil (States of Pernambuco and São Paulo) (Barros et al. 2014, Govaerts et al. 2014).

Examined material: BRAZIL. Pernambuco: Jaqueira, RPPN Frei Caneca, 29-V-2012, fl., E. Pessoa 933 (NY, RB, UFP); 30-V-2012, fl., E. Pessoa et al. 938 (NY, RB, UFP); 11-III-2011, fl., E. Pessoa et al. 548 (UFP).

78. Trichocentrum fuscum Lindl., Edwards's Bot. Reg. 23: t. 1951. 1837.

Figure $4 \mathrm{~s}$

This epiphyte differs from Comparettia barkeri by its green leaves and racemose inflorescence. It occurs 
in forested areas and it is known from French Guyana, Suriname, Venezuela, Ecuador and Brazil, where it is widely distributed (Barros et al. 2014, Govaerts et al. 2014).

Examined material: BRAZIL. Pernambuco: Jaqueira, RPPN Frei Caneca, 30-V-2012, fl., E. Pessoa et al. 956 (UFP).

79. Vanilla aff. mexicana Mill., Gard. Dict. ed. 8: 1. 1768.

This hemi-epiphyte differs from $V$. aff. pompona by the texture (membranaceous) and shape (elliptic) of the leaf blades and the length of the internodes $(<7.0 \mathrm{~cm}$ long). The identity of the collected specimen is still obscure due to the lack of flowers, but based on vegetative and fruit characters, it appears to belong to the $V$. mexicana group. It is found in forested areas.

Examined material: BRAZIL. Pernambuco: Jaqueira, RPPN Frei Caneca, 31-I-2013, fr., E. Pessoa et al. 1060 (UFP).

80. Vanilla cf. pompona Schiede, Linnaea 4: 573. 1829.

Figure $3 \mathrm{t}$

This hemi-epiphyte differs from $V$. aff. mexicana by its coriaceous, oblong leaves, and longer internodes $(>9.0 \mathrm{~cm}$ long). It occurs in forested areas and it is widely distributed in the Neotropics (Govaerts et al. 2014); in Brazil, it is cited to the Amazon and Atlantic Forests (States of Amazonas, Amapá, Tocantins, Rondônia, Paraíba, Pernambuco, Mato Grosso and Minas Gerais) (Barros et al. 2014).

Examined material: BRAZIL. PeRnAmbuco: Jaqueira, RPPN Frei Caneca, 10-III-2011, fr., E. Pessoa et al. 499 (UFP).

Additional material: BRAZIL. Pernambuco: São Lourenço da Mata, Estação Ecológica de Tapacurá, 17-XI-2010, fl., E. Pessoa et al. 403 (UFP, RB)

81. Zygostates bradei (Schltr.) Garay, Bot. Mus. Leafl. 21:263. $1967 \equiv$ Dipteranthus bradei Schltr., Anexos Mem. Inst. Butantan, Secç. Bot. 1(4): 651922. Figure $4 \mathrm{t}$

This epiphyte is easily recognized among the species in the area by its flowers with serrate sepals. It occurs in forested areas and it is endemic to the Brazilian Atlantic Forest (States of Pernambuco, Alagoas, São Paulo, Paraná and Santa Catarina) (Barros et al. 2014, Govaerts et al. 2014). It is cited as endangered by Biodiversitas (2008). There are large populations of this species in the Serra do Urubu.
Examined material: BRAZIL. Pernambuco: Jaqueira, RPPN Frei Caneca, 29-I-2013, fl., E. Pessoa et al. 1047 (UFP); Lagoa dos Gatos, RPPN Pedra D'Anta, 17-XII-2010, fl. e fr., E. Pessoa et al. 431 (NY, RB, UFP).

\section{Acknowledgments}

We are indebted to the organizations, which funded our field research, including $\mathrm{CNPq}$, the US National Science Foundation (DEB-0946618), Velux Stiftung as well as the Beneficia Foundation.

\section{Literature cited}

Alves-Araújo, A. \& Alves, M. 2011. Two new species of Pouteria (Sapotaceae) from the Atlantic Forest. Systematic Botany 36: 1005-1007.

Alves-Araújo, A. \& Alves, M. 2012a. Two new species and a new combination of Neotropical Sapotaceae. Brittonia 64: 23-29.

Alves-Araújo, A. \& Alves, M. 2012b. Pouteria ciliata, $P$. confusa, $P$. nordestinensis and $P$. velutinocarpa spp. nov. (Sapotaceae) from Brazil. Nordic Journal of Botany 29: 1-8.

Amorim, B.S. \& Alves, M. 2012. A new species of Eugenia (Myrtaceae) from the Atlantic Forest, northeastern Brazil. Systematic Botany 37: 694-698.

Amorim, B.S., Lourenco, A.R. \& Alves, M. 2013. A new species of Myrcia (Myrteae, Myrtaceae) from the Atlantic Forest of southern Bahia, Brazil. Brittonia 65: 296-300.

Araujo, A \& Alves, M. 2013. Aristolochia setulosa (Aristolochiaceae) a new species form the notheastern Brazil. Brittonia 65: 301-304.

Barros, F., Vinhos, F., Rodrigues, V.T., Barberena, F.F.V.A., Fraga, C.N., Pessoa, E.M., Forster, W. \& Menini Neto, L. 2014. Orchidaceae In: Lista de Espécies da Flora do Brasil. Jardim Botânico do Rio de Janeiro. Available at $<$ http://floradobrasil.jbrj.gov. br/jabot/floradobrasil/FB179> (access in 11-III-2014).

Biodiversitas. 2008. Lista da Flora Brasileira Ameaçada de Extinção. Orchidaceae. Available at <http://www. biodiversitas.org.br/floraBr/ grupo3fim.asp $>$ (access in 23-IV-2010).

Carnevali, G., Ramírez-morillo, I.M., RomeroGonzález, G.A., Vargas, C.A. \& Foldats, E. 2003. Orchidaceae. In: P.E. Berry, K. Yatskievych. \& B.K. Holts (eds.). Flora of the Venezuelan Guayana, v. 7. Missouri Botanical Garden, Saint Louis. pp. 200-618.

Coelho, M.M. \& Amorim,A.M. 2014. Floristic composition of the Montane Forest in the Almadina-Barro Preto axis, Southern Bahia, Brazil. Biota Neotropica 14: 1-41.

Costa-Lima, J.L. \& Alves, M. 2013. A new species of Erythroxylum (Erythroxylaceae) from the Brazilian Atlantic Forest. Phytotaxa 141: 55-60. 
Costa-Lima, J.L., Alves, M. \& Loyola, M.I. 2014. A new species of Erythroxylum (Erythroxylaceae) from northeastern Brazil. Brittonia 66: 60-64.

Dunsterville, G.C.K. \& Garay, L.A. 1959. Venezuelan Orchids Illustrated, v. 1. Andre Deutsch, London.

Dunsterville, G.C.K. \& Garay, L.A. 1961. Venezuelan Orchids Illustrated, v. 2. Andre Deutsch, London.

Dunsterville, G.C.K. \& Garay, L.A. 1965. Venezuelan Orchids Illustrated, v. 3. Andre Deutsch, London.

Dunsterville, G.C.K. \& Garay, L.A. 1966. Venezuelan Orchids Illustrated, v. 4. Andre Deutsch, London.

Dunsterville, G.C.K. \& Garay, L.A. 1972. Venezuelan Orchids Illustrated, v. 5. Andre Deutsch, London.

Dunsterville, G.C.K. \& Garay, L.A. 1976. Venezuelan Orchids Illustrated, v. 6. Andre Deutsch, London.

Gonçalves, E. \& Lorenzi, H. 2007. Morfologia Vegetal organografia e dicionário ilustrado de morfologia das plantas vasculares. Instituto Plantarum, Nova Odessa.

Govaerts, R., Pfahl, J., Campacci, M.A., Holland Baptista, D., Tigges, H., Shaw, J., Cribb, P., George, A., Kreuz, K. \& Wood, J. 2014. World Checklist of Orchidaceae. The Board of Trustees of the Royal Botanic Gardens, Kew. Available at $<$ http://apps.kew. org/wcsp/> (access in 9-III-2014).

Harris, J. \& Harris, M. 2001. Plant identification terminology - an illustrated glossary. 2 ed. Spring Lake Publishing, Payson.

Lourenço, A.R., Amorim, B.S. \& Alves, M. 2013. Eugenia pipensis, a new species of Eugenia sect. Umbellatae (Myrtaceae) from northeastern Brazil. Phytotaxa 104: 30-34.

Marinho, L.C. \& Azevedo, C.O. 2013. Orchidaceae na Reserva do Poço Escuro, Vitória da Conquista, Bahia, Brasil. Sitientibus série Ciências Biológicas 13: 1-14.

Martinelli, G. \& Moraes, M.A. 2013. Livro Vermelho da Flora do Brasil. Jardim Botânico do Rio de Janeiro, Rio de Janeiro.

Melo, A. \& Alves, M. 2012. A discovery of Lacandonia (Triuridaceae) in Brazil. Phytotaxa 40: 21-25.

Ministério do Meio Ambiente. 2008. Lista Oficial das Espécies da Flora Brasileira Ameaçadas de Extinção. Instrução Normativa MMA no 06/2008. Available at $<$ www.ibama.gov.br/sisbio> (access in 3-IX-2009).

Mittermeier, R.A., Robles, G.P., Hoffmann, M., Pilgrim, J., Brooks, T., Mittermeier, C.G., Lamoreux, J. \& Fonseca, G.A.B. 2004. Hotspots Revisited. Garza Garcia N.L. CEMEX, Mexico City.

Mori, S.A., Mattos-Silva, L.A., Lisboa, G. \& Coradin, L. 1985. Manual de Manejo do Herbário Fanerogâmico. 2 ed. CEPLAC/CEPEC, Ilhéus.

Myers, N., Mittermeier, R., Mittermeier, C., Fonseca, G. \& Kent, J. 2000. Biodiversity hotspots for conservation priorities. Nature 403: 845-853.

Pabst, G.F.J. \& Dungs, F. 1975. Orchidaceae Brasilienses. v. 1. Kurt Schmersow, Hildesheim.
Pabst, G.F.J. \& Dungs, F. 1977. Orchidaceae Brasilienses. v. 2. Kurt Schmersow, Hildesheim.

Pessoa, E. \& Alves, M. 2011. Orchidaceae Juss. na Serra de Itabaiana, Sergipe, Brasil. Revista Caatinga 24: 102-114.

Pessoa, E. \& Alves, M. 2012. Flora da Usina São José, Igarassu, Pernambuco: Orchidaceae. Rodriguesia 63: 341-356.

Pessoa, E. \& Alves, M. 2014. A new species and a new combination in Stelis (Orchidaceae) from South America. Brittonia 66: 156-159.

Pessoa, E., Barros, F., Alves, M. 2014a. Specklinia integripetala and S. ianthina spp. nov. (Orchidaceae) from northeastern Brazil. Nordic Journal of Botany 32: $129-132$.

Pessoa, E., Felix, L.P. \& Alves, M. 2014b. A new Epidendrum (Laellinae-Orchidaceae) from the Atlantic Forest of northeastern Brazil: Evidence from morphology and cytogenetics. Brittonia 66: 347-352.

Prance, G.T. 1982. Forest refuges: evidences from woody angiosperms. In: G.T. Prance (ed.). Biological diversification in the tropics. Columbia University Press, New York. pp. 137-158.

Ranta, P., Blom, T., Niemela, J., Joensuu, E. \& Siitonen, M. 1998. The fragmented Atlantic rain forest of Brazil: size, shape and distribution of forest fragments. Biodiversity and Conservation 7: 385-403.

Siqueira-Filho, J.A. \& Felix, L.P. 2006. Bromélias e Orquídeas. In: K.C. Pôrto J.S. Almeida-Cortez \& M. Tabarelli (org.). Diversidade Biológica e Conservação da Floresta Atlântica ao Norte do Rio São Francisco. Ministério do Meio Ambiente, Brasília. pp. 219-228.

Secretaria de Ciência, Tecnologia e Meio Ambiente. 1994. Diagnóstico do Setor Florestal do Estado de Pernambuco. SECTMA-PE, Recife.

Stehmann, J.R., Forzza, R.C., Sobral, M. \& Kamino, L.H.Y. 2009. Gimnospermas e Angiospermas. In: J.R. Stehmann, R.C. Forzza, A. Salino, M. Sobral, D.P. Costa, \& L.H.Y. Kamino (eds.). Plantas da Floresta Atlântica. Jardim Botânico do Rio de Janeiro, Rio de Janeiro. pp. 27-37.

Terra, M., Farias, A.D., Alves-Araújo, A. \& Alves, M. 2013. Pradosia restingae sp. nov. (Sapotaceae) from the Atlantic Forest, Brazil. Nordic Journal of Botany 31: 437-441.

Thiers, B. 2014. Index Herbariorum: a global directory of public herbaria and associated staff. New York Botanical Garden's Virtual Herbarium. Available at $<$ http://sweetgum.nybg.org/ih/> (access in 8-III-2014).

Toscano-de-Brito, A.L. \& Cribb, P. 2005. Orchidaceae da Chapada Diamantina. Nova Fronteira, São Paulo.

Veloso, H.P. 1992. Sistema fitogeográfico. In: Manual técnico da vegetação brasileira. Instituto Brasileiro de Geografia e Estatística, Rio de Janeiro. pp. 9-38. 